\title{
Properties and evolution of biomass burning organic aerosol from Canadian boreal forest fires
}

\author{
M. D. Jolleys ${ }^{1}$, H. Coe ${ }^{1}$, G. McFiggans ${ }^{1}$, J. W. Taylor ${ }^{1}$, S. J. O’Shea ${ }^{1}$, M. Le Breton ${ }^{1}$, S. J.-B. Bauguitte ${ }^{2}$, S. Moller ${ }^{3}$, \\ P. Di Carlo ${ }^{4,5}$, E. Aruffo ${ }^{4,5}$, P. I. Palmer ${ }^{6}$, J. D. Lee $^{3}$, C. J. Percival ${ }^{1}$, and M. W. Gallagher ${ }^{1}$ \\ ${ }^{1}$ Centre for Atmospheric Science, School of Earth, Atmospheric and Environmental Science, \\ University of Manchester, Manchester, UK \\ ${ }^{2}$ Facility for Airborne Atmospheric Measurements, Bedford, UK \\ ${ }^{3}$ National Centre for Atmospheric Science (NCAS), Department of Chemistry, University of York, York, UK \\ ${ }^{4}$ Centre of Excellence CETEMPS, University of L'Aquila, L'Aquila, Italy \\ ${ }^{5}$ Department of Physical and Chemical Sciences, University of L'Aquila, L'Aquila, Italy \\ ${ }^{6}$ School of Geosciences, University of Edinburgh, Edinburgh, UK
}

Correspondence to: M. D. Jolleys (matthew.jolleys@ manchester.ac.uk)

Received: 4 August 2014 - Published in Atmos. Chem. Phys. Discuss.: 1 October 2014

Revised: 5 February 2015 - Accepted: 23 February 2015 - Published: 18 March 2015

\begin{abstract}
Airborne measurements of biomass burning organic aerosol (BBOA) from boreal forest fires reveal highly contrasting properties for plumes of different ages. These measurements, performed using an Aerodyne Research Inc. compact time-of-flight aerosol mass spectrometer (C-ToF-AMS) during the BORTAS (quantifying the impact of BOReal forest fires on Tropospheric oxidants over the Atlantic using Aircraft and Satellites) experiment in the summer of 2011, have been used to derive normalised excess organic aerosol (OA) mass concentrations $(\triangle \mathrm{OA} / \Delta \mathrm{CO})$, with higher average ratios observed closer to source $(0.190 \pm 0.010)$ than in the far-field $(0.097 \pm 0.002)$. The difference in $\triangle \mathrm{OA} / \triangle \mathrm{CO}$ between fresh and aged plumes is influenced by a change in dominant combustion conditions throughout the campaign. Measurements at source comprised 3 plume interceptions during a single research flight and sampled largely smouldering fires. Twentythree interceptions were made across four flights in the farfield, with plumes originating from fires occurring earlier in the campaign when fire activity had been more intense, creating an underlying contrast in emissions prior to any transformations associated with aging. Changing combustion conditions also affect the vertical distribution of biomass burning emissions, as aged plumes from more flaming-dominated fires are injected to higher altitudes of up to $6000 \mathrm{~m}$. Proportional contributions of the mass-to-charge ratio $(\mathrm{m} / \mathrm{z}) 60$
\end{abstract}

and 44 peaks in the AMS mass spectra to the total OA mass (denoted $f_{60}$ and $f_{44}$ ) are used as tracers for primary and oxidised BBOA, respectively. $f_{44}$ is lower on average in near-field plumes than those sampled in the far-field, in accordance with longer aging times as plumes are transported a greater distance from source. However, high levels of $\Delta \mathrm{O}_{3} / \Delta \mathrm{CO}$ and $-\log \left(\mathrm{NO}_{\mathrm{x}} / \mathrm{NO}_{\mathrm{y}}\right)$ close to source indicate that emissions can be subject to very rapid oxidation over short timescales. Conversely, the lofting of plumes into the upper troposphere can lead to the retention of source profiles after transportation over extensive temporal and spatial scales, with $f_{60}$ also higher on average in aged plumes. Evolution of OA composition with aging is comparable to observations of $\mathrm{BB}$ tracers in previous studies, revealing a consistent progression from $f_{60}$ to $f_{44}$. The elevated levels of oxygenation in aged plumes, and their association with lower average $\triangle \mathrm{OA} / \triangle \mathrm{CO}$, are consistent with OA loss through evaporation during aging due to a combination of dilution and chemical processing, while differences in combustion conditions throughout the campaign also have a significant influence on BBOA production and composition. 


\section{Introduction}

The BORTAS (quantifying the impact of BOReal forest fires on Tropospheric oxidants over the Atlantic using Aircraft and Satellites) campaign was a major international research effort to improve understanding of the properties and evolution of biomass burning (BB) plumes. BB emissions form a major source of atmospheric particulate matter on a global scale, contributing around $90 \%$ of the total primary organic aerosol (OA) (Bond et al., 2004). The radiative effects of atmospheric aerosols represent one of the major sources of uncertainty with regard to influences on climate change (Textor et al., 2006; Forster et al., 2007). Given the prominence of OA in global aerosol budgets (Zhang et al., 2007; Jimenez et al., 2009), limited understanding of $\mathrm{BB}$ emissions, and more specifically biomass burning organic aerosol (BBOA) emissions, forms an important component of this uncertainty. Improved projection of climate change impacts through global climate model simulation is dependent on more robust parameterisation of the constituent drivers, constrained by direct measurements. Several fundamental aspects of the BBOA lifecycle remain poorly characterised (Hallquist et al., 2009), including the conditions and processes controlling formation and the effects of transformations occurring during aging, such as gas-particle partitioning of low volatility organic compounds following photo-oxidation, heterogeneous reactions with existing OA and losses through dilution-based evaporation or volatilisation (Reid et al., 2005; Grieshop et al., 2009; DeCarlo et al., 2010; Hennigan et al., 2011). Variability at source has been shown to be extensive, in response to changes in both fuel properties and combustion conditions (McMeeking et al., 2009; Jolleys et al., 2012, 2014). The importance of secondary organic aerosol (SOA) in aging plumes is also particularly unclear. Substantial SOA formation as a result of photochemical processing has been demonstrated in laboratory experiments, increasing OA concentrations by up to a factor of 4 over several hours (Grieshop et al., 2009; Hennigan et al., 2011; Heringa et al., 2011). However, under ambient conditions the importance of SOA addition relative to primary (POA) emissions is more disputable. Despite widespread evidence for the increasing oxygenation of BBOA with aging (Capes et al., 2008; DeCarlo et al., 2008; Cubison et al., 2011; Jolleys et al., 2012), net mass enhancements are not observed consistently. The underlying causes of this variable SOA contribution, including the implications of initial OA composition, also remain ambiguous and require further refinement.

The BORTAS campaign is described in detail by Palmer et al. (2013), with an overview of measurements used within this analysis given here. BORTAS took place across several regions of Canada between the 12 July and 3 August in both 2010 and 2011, although activity during the 2010 deployment (BORTAS-A) was limited to ground-based measurements at a main ground station located at Dalhousie Univer- sity in Halifax, Nova Scotia, along with ozonesonde launches from a network of seven sites across central and eastern Canada and supporting satellite observations (Parrington et al., 2012). Airborne measurements were carried out during BORTAS-B in 2011, providing all data contributing towards this study. The UK Facility for Airborne Atmospheric Measurements (FAAM) BAe-146 Atmospheric Research Aircraft (ARA) performed a total of 15 flights, including 11 dedicated science flights between the 15 and 31 July. Research flights primarily originated from Halifax and largely involved surveying areas adjacent to the Gulf of St. Lawrence and the North Atlantic. A predominant source region in northwestern Ontario (approximately $52.5^{\circ} \mathrm{N}, 93.5^{\circ} \mathrm{W}$ ) has been identified for the majority of plumes sampled throughout BORTAS, although more disperse fires were also active in northern Alberta and the Northwest Territories (Palmer et al., 2013; Parrington et al., 2013). As the majority of plumes from fires in this region were encountered at a distance of several thousand kilometres downwind, emissions would have undergone substantial processing prior to sampling, with estimated photochemical ages between 1-11 days. A single flight to the Ontario source region also sampled active fires directly at source, providing a valuable inventory of fresh plume measurements and enabling comparison of emissions in the near and far-field. Tracks of all flights included within this analysis are shown in Fig. 1. Back trajectories for air masses encountered throughout the durations of flights B621-624 are presented by O'Shea et al. (2013a), detailing the transport pathways of plumes and agreement with active fire locations, while Taylor et al. (2014) provide air mass histories for individual plumes sampled during flight B626. Comparison of emissions of different ages is subject to potential contrasts in fire behaviour, given that each set of measurements were obtained at different stages of the campaign. Fire activity within the region peaked between the 17 and 19 July (Fig. 2), with emissions from these fires intercepted far downwind. Plumes from active fires within this region were also sampled at source on the 26 July (flight B626), representing the only measurements of fresh plumes from BORTAS. However, by this time fire activity had significantly abated, bringing about a change in combustion conditions to yield smaller, less intense fires more typically dominated by smouldering combustion (O'Shea et al., 2013a). The more intense period of fires earlier in the campaign is expected to have involved larger events with a more prominent flaming combustion phase, as indicated by the detection of pronounced smoke plumes at altitudes of up to approximately $7000 \mathrm{~m}$ over the North Atlantic (Palmer et al., 2013). As a result, any comparison of fresh and aged plumes during BORTAS must also account for this disparity in source conditions. While such a scenario would reduce the potential to evaluate the continuous evolution of smoke plumes from source into the ambient atmosphere, and prevent direct comparison of near and far-field plumes derived from similar 


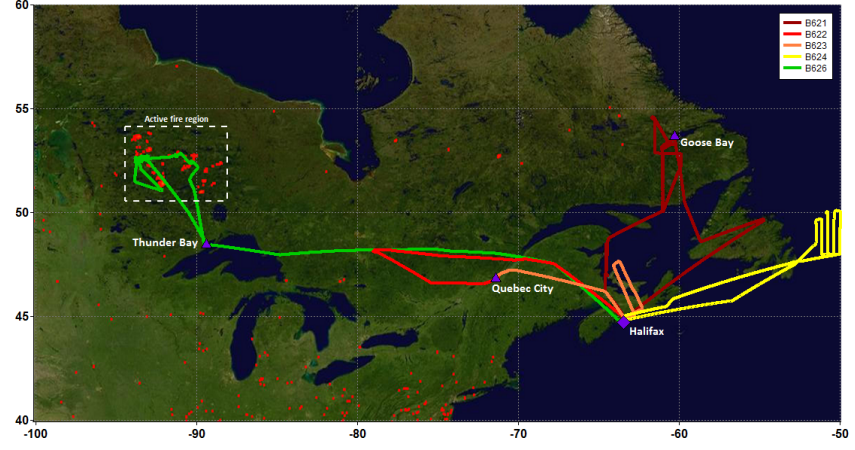

Figure 1. Flight tracks for flights B621-624 and B626 during BORTAS, overlain on a MODIS accumulated 10 day fire map for eastern Canada during the period 20-29 July 2011. Images courtesy of MODIS Rapid Response Project at NASA/GSFC.

combustion conditions, it also provides a baseline for conditions at source.

\section{Background}

\subsection{Instrumentation and measurements}

A wide array of instrumentation performing particulate and gas phase measurements were deployed throughout BORTAS. This study focuses primarily on the analysis of OA mass and composition data obtained from an Aerodyne Research Inc. compact time-of-flight aerosol mass spectrometer (C-ToF-AMS; Drewnick et al., 2005; Canagaratna et al., 2007). The AMS provides highly time-resolved mass concentrations of sub-micron, non-refractory aerosol, and a broad chemical characterisation across a complete range of constituent ion mass-to-charge ratios $(\mathrm{m} / \mathrm{z})$. Operation of the AMS, including calibration and necessary correction factors, during aircraft deployment (Bahreini et al., 2003) and specifically onboard the BAe-146 (Crosier et al., 2007; Morgan et al., 2009; Taylor et al., 2014) have been described in detail. Refractory black carbon (BC) was measured using a Droplet Measurement Technologies single particle soot photometer (SP-2; Schwarz et al., 2006; Taylor et al., 2014). Although analysis of the chemical and optical properties of single BC particles was not performed as part of this study, mass concentrations in smoke plumes, particularly in relation to $\mathrm{OA}$ concentrations, were used as a means of evaluating the proportional contributions of different combustion phases. A range of gas phase measurements were undertaken on the BAe-146, including species used as tracers for both primary emissions and photochemical processing. $\mathrm{CO}$ mixing ratios were measured with an Aerolaser AL5002 UV fluorescence analyser and $\mathrm{O}_{3}$ by a Thermo Scientific TEi49C UV photometric analyser as part of the standard complement of instrumentation for BAe-146 science flights. Additional instrumentation included a chemical ionisation mass spectrometer
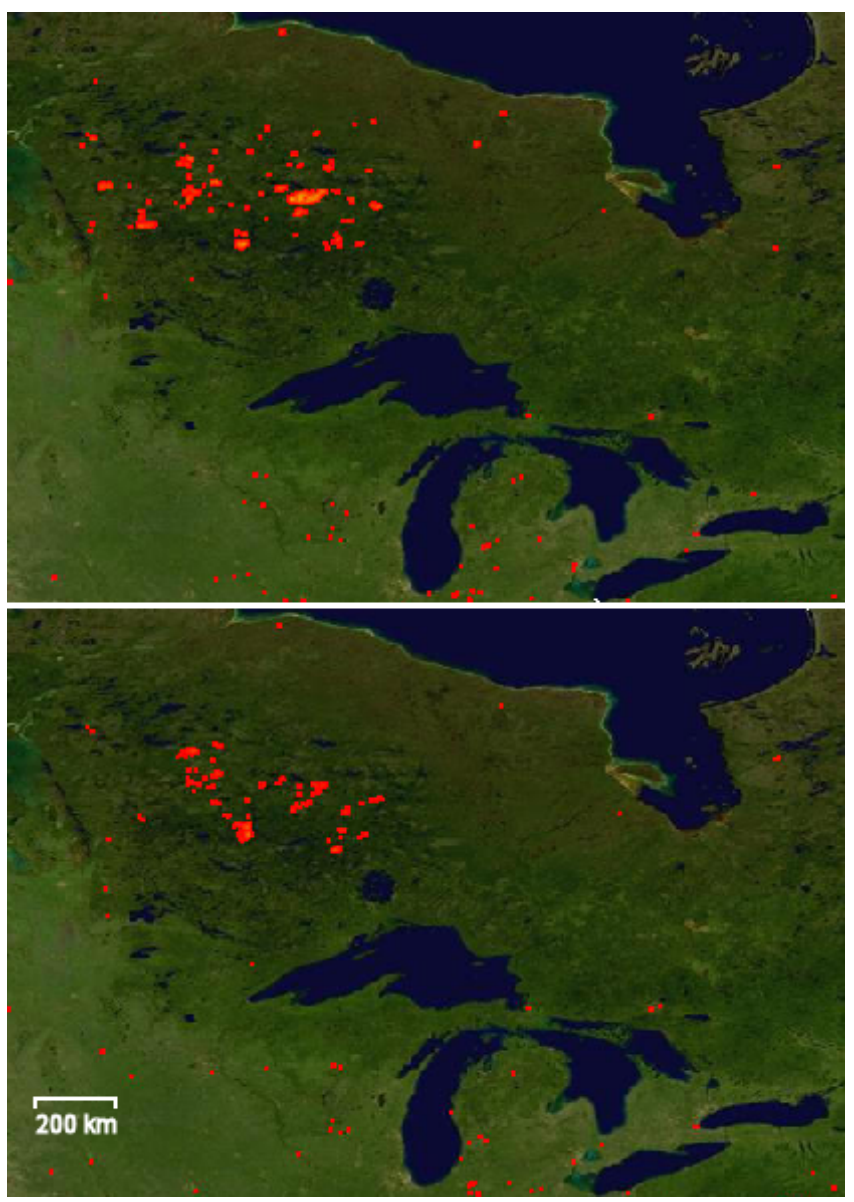

Figure 2. MODIS fire maps showing the reduction in fire activity in north-western Ontario between the 10 day periods of 10-19 July 2011 (top) and 20-29 July 2011 (bottom).

(CIMS; Nowak et al., 2007; Le Breton et al., 2012) providing real-time measurements of $\mathrm{HCN}$, which is widely used as a tracer for $\mathrm{BB}$ emissions given that vegetation fires constitute its primary global source ( $\mathrm{Li}$ et al., 2000; Sinha et al., 2003; Yokelson et al., 2007). $\mathrm{NO}_{\mathrm{x}}\left(\mathrm{NO}+\mathrm{NO}_{2}\right)$ and $\mathrm{NO}_{\mathrm{y}}\left(\mathrm{NO}_{\mathrm{x}}\right.$ oxidation products, including $\mathrm{HNO}_{3}$ and $\mathrm{N}_{2} \mathrm{O}_{5}$ ) act as important tracers for oxidation in aging plumes, and were measured respectively by an Air Quality Design Inc. chemiluminescence $\mathrm{NO}_{\mathrm{x}}$ analyser and by thermal dissociation-laser induced fluorescence (TD-LIF; Di Carlo et al., 2013). The assembly of gas phase measurements used within this analysis was completed by $\mathrm{CO}_{2}$ mixing ratios from a Los Gatos Research Inc. cavity enhanced absorption spectrometer-based fast greenhouse gas analyser (FGGA; O'Shea et al., 2013b). Aerosol size distributions in the range $20-350 \mathrm{~nm}$ were obtained from a scanning mobility particle sizer (SMPS), with integrated distributions over this size range used as an approximation of particle number concentration. 


\subsection{Data selection}

Measurements from 5 BORTAS flights (B621-B624 and B626) were included in this analysis. Flight B626 provided the only measurements of fresh BB plumes throughout the campaign, with all other flights sampling air masses downwind of the source region at ages of several days. Data were screened in order to isolate emissions with a biomass burning influence, resulting in a total number of 26 valid plume interceptions ( 3 fresh and 23 aged) across the 5 flights. Screening was performed using the guidelines proposed by Capes et al. (2008) and Jolleys et al. (2012) based upon minimum $\Delta \mathrm{CO}$ (the excess $\mathrm{CO}$ concentration above background levels) and absolute number concentrations. Respective thresholds of $20 \mathrm{ppb}$ and $2000 \mathrm{~cm}^{-3}$ were applied for $\Delta \mathrm{CO}$ and number concentration. Background concentrations for $\mathrm{CO}$ and other species were calculated for each flight according to minimum observed concentrations, which were applied to all measurements throughout the full vertical extent of sampling, given the limited variation in background concentrations with altitude. $\mathrm{CO}_{2}$ was the only exception, with high variability both in and out of plume making it difficult to define an appropriate background concentration. As a result, only absolute concentrations are reported for $\mathrm{CO}_{2}$, as opposed to excess values. A threshold of 0.003 was used for $f_{60}$, representing the ratio of levoglucosan-like species, which correspond to the $m / z, 60$ peak in the AMS mass spectra (Schneider et al., 2006; Alfarra et al., 2007), to the total OA mass. This threshold is based upon observed background levels of $f_{60}$ in OA emissions from urban and biogenic sources where BB influences are absent (Cubison et al., 2011; Aiken et al., 2009; DeCarlo et al., 2008). Levoglucosan and other anhydrous sugars such as mannosan and galactosan have been shown to be strongly associated with primary BB emissions (Simoneit et al., 1999; Iinuma et al., 2007; Sullivan et al., 2008; Lee et al., 2010). All data were also averaged to the temporal resolution of the AMS ( $\sim 8$ second time step on average) to enable direct comparison of different species.

Alternative screening procedures for BB influences have been applied throughout separate analyses of BORTAS data (Palmer et al., 2013). Concentrations of trace gases primarily produced by fire sources, including $\mathrm{HCN}$ and $\mathrm{CH}_{3} \mathrm{CN}$, are commonly used as indicators for BB plumes (Li et al., 2000; Yokelson et al., 2007; Crounse et al., 2009; Yokelson et al., 2009; Akagi et al., 2011). A scheme using a HCN concentration threshold of six times the standard deviation $(6 \sigma)$ has been used during BORTAS in an analysis of high sensitivity $1 \mathrm{~Hz}$ CIMS measurements and their consistency with $\mathrm{CO}$ and $\mathrm{CH}_{3} \mathrm{CN}$ concentrations (Le Breton et al., 2013). However, as many previous data sets do not include HCN measurements, a screening procedure using only $\triangle \mathrm{OA}, \triangle \mathrm{CO}$ and number concentration data has been applied here, so that the approach can be used consistently across a broader range of data. This approach performs well when compared to the Le Breton et al. method, producing similarly strong corre- lations between $\triangle \mathrm{HCN}$ and $\triangle \mathrm{CO}$ for flights B621, B622, B624 and B626 $\left(R^{2}=0.64,0.52,0.84\right.$ and 0.93$)$ as the $6 \sigma$ technique $\left(R^{2}=0.83,0.46,0.82\right.$ and 0.81$)$. HCN was not measured during B623, preventing comparison of classification schemes for this flight. Several flights carried out later in the campaign (B628-B630) also measured highly aged plumes with a photochemical age of up to 11 days (Palmer et al., 2013). However, correlations between $\triangle \mathrm{OA}$ and $\Delta \mathrm{CO}$ throughout these flights were exceptionally weak, yielding $R^{2}$ values consistently well below 0.1 , contrasting with values in the range 0.39-0.74 for flights B621-B624 and B626. These weak correlations from later flights suggest that sampled air masses lack a common emission source and instead represent extensive mixtures of different plumes following dispersion, or that emissions have been differentially processed to the extent that representative properties can no longer be distinguished. As a result, data from these flights were omitted from this analysis.

Throughout this study, extensive use is made of normalised measurements as a means of assessing the relative abundances of different species. Normalising to a co-emitted, non-reactive tracer such as $\Delta \mathrm{CO}$ provides an emission ratio (ER) when calculated at source. Normalised excess mixing ratios (NEMR) are used to represent these values for any other point in a plume away from source along a Lagrangian trajectory, and account for the effects of dispersion as concentrations in plumes decrease through dilution. These ratios can also be used as a marker for potential SOA formation, as the longer atmospheric lifetime of $\mathrm{CO}(\sim 1$ month) relative to that of OA (on the order of several weeks) makes it likely that any enhancement of the ratio between the two species will be a result of the addition of OA, rather than increased removal of $\mathrm{CO}$ in isolation.

\section{Results and discussion}

\subsection{Spatial and temporal variability in BB emissions properties}

Measurements of OA in BB plumes during the BORTAS flights included within this analysis encompassed a wide range of ages, from at source to up to 5 days after emission. The extent of this diversity in age contributed to a high level of variability in plume properties, both across separate research flights and between individual plumes encountered in different periods of the same flight. Excess OA concentrations measured in-plume ranged from close to zero to around $180 \mu \mathrm{g} \mathrm{m}^{-3}$, with maximum $\Delta \mathrm{CO}$ concentrations approaching $1000 \mathrm{ppb}$. Vertical profiles of both species are shown in Fig. 3, revealing an overall increase in concentrations throughout the boundary layer to a peak at around $2000 \mathrm{~m}$, before declining to background levels through the free troposphere. Significant elevations in both $\triangle \mathrm{OA}$ and $\triangle \mathrm{CO}$ occurred close to ground level, most likely as a result of influ- 

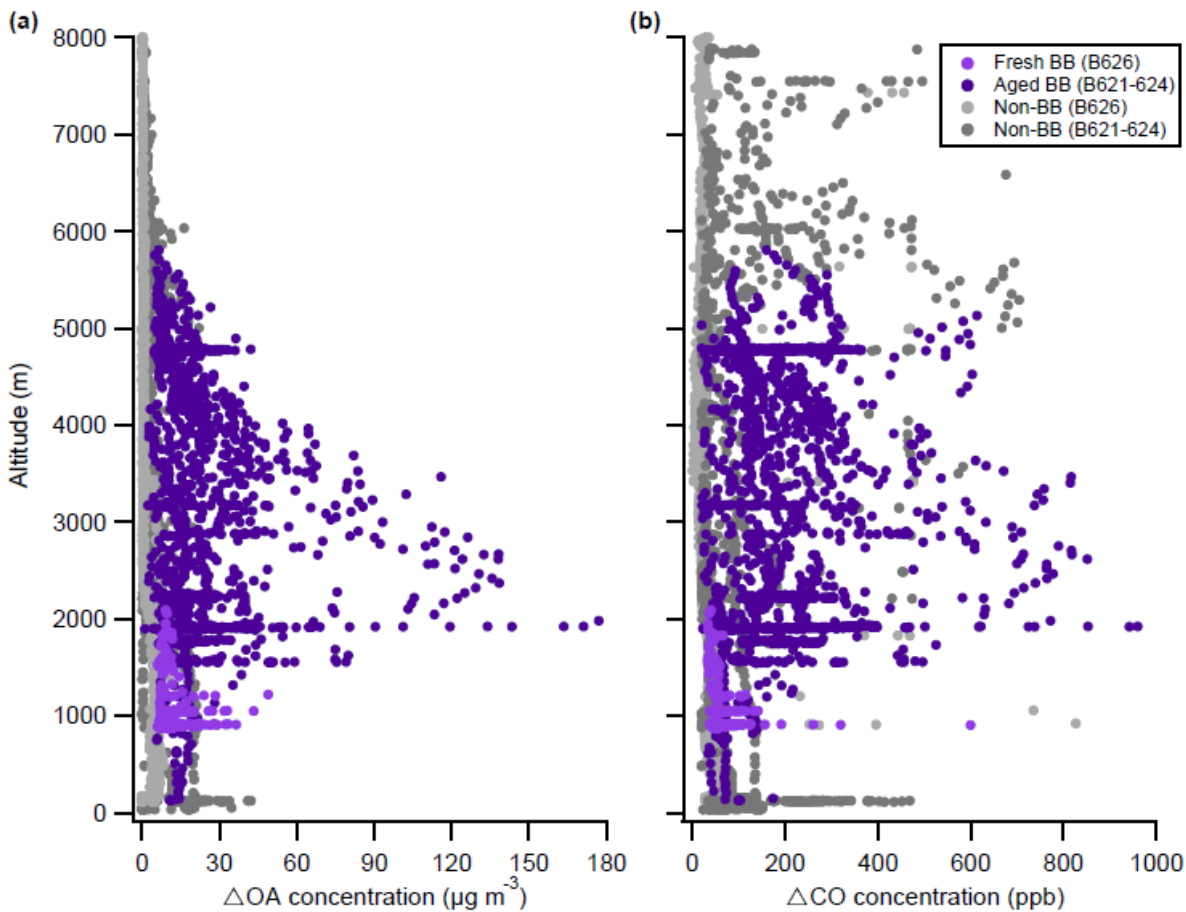

Figure 3. Vertical profiles of (a) $\triangle \mathrm{OA}$ and (b) $\Delta \mathrm{CO}$ in fresh and aged plumes, together with concentrations in air masses free from the influence of biomass burning.

ence from local sources. The observed decrease in concentration with altitude is more marked for $\triangle \mathrm{OA}$, which returns to background levels by $6000 \mathrm{~m}$. Variability in $\triangle \mathrm{CO}$ is much greater than $\triangle \mathrm{OA}$ at higher altitudes. $\triangle \mathrm{CO}$ concentrations of up to $800 \mathrm{ppb}$ were observed between $5000-8000 \mathrm{~m}$, whereas $\Delta \mathrm{OA}$ did not exceed $30 \mu \mathrm{g} \mathrm{m}^{-3}$. This disparity is attributed to the removal of OA from plumes encountered during flight B622 (20 July) by precipitation prior to sampling following advection through clouds, as corroborated by meteorological observations and back trajectory models (Griffin et al., 2013; Taylor et al., 2014). Wet deposition of aerosol reduced $\Delta \mathrm{OA}$ to background levels, while $\Delta \mathrm{CO}$ concentrations remained elevated to similar levels as observed at lower altitudes. Despite their biomass burning origin, the absence of $\mathrm{OA}$ and $\mathrm{BC}$ from these plumes resulted in their omission from this analysis.

The change in combustion conditions between different periods of BORTAS is reflected in the contrast between loadings of particulate and gas-phase species. Concentrations of the majority of sampled species in aged plumes during flights B621-B624, including $\triangle \mathrm{OA}, \mathrm{CO}, \mathrm{CO}_{2}$ and $\mathrm{BC}$, consistently exceeded those at source from B626, irrespective of the effect of dilution as plumes dispersed into the ambient atmosphere. During flight B626, $\triangle \mathrm{OA}$ peaked at around $50 \mu \mathrm{g} \mathrm{m}^{-3}$, with concentrations in more aged plumes exceeding this level by a factor of 3.6. $\triangle \mathrm{CO}$ concentrations were also significantly elevated in aged plumes relative to fresh emissions. The contrast in properties between plumes of different ages is likely to be primarily affected by a change in the size and intensity of fires, rather than combustion phase alone, given the stronger association of both $\mathrm{OA}$ and $\mathrm{CO}$ production with predominantly smouldering combustion in the latter stages of fire evolution (Reid et al., 2005).

While the higher concentrations identified in aged plumes may be influenced to some extent by contributions from $\mathrm{SOA}$, initial indications from calculated $\triangle \mathrm{OA} / \triangle \mathrm{CO}$ ratios suggest this contribution did not provide any net increase in OA loadings. Figure 4 shows $\triangle \mathrm{OA} / \triangle \mathrm{CO}$ for all five analysed BORTAS flights, with average values determined from the gradient of linear least squares regressions. Using this approach reveals that the average $\triangle \mathrm{OA} / \Delta \mathrm{CO}$ close to source $(0.190 \pm 0.010$, where uncertainty represents the standard deviation in the fit) exceeds that for aged plumes $(0.097 \pm 0.002)$ by around $50 \%$, with an overall campaign average of $0.104 \pm 0.003$. Average ratios for individual flights sampling aged emissions range from $0.056 \pm 0.003$ (B624) to $0.114 \pm 0.003$ (B622), giving an overall range of 0.058 . The level of average $\triangle \mathrm{OA} / \triangle \mathrm{CO}$ for fresh emissions from boreal forest fires during BORTAS falls between the upper extent derived from the eucalypt forests of northern Australia during the Aerosol and Chemical Transport in Tropical Convection (ACTIVE) campaign (0.329), and lower ratios from several other campaigns where OA enhancements were comparatively reduced (0.019-0.065; Jolleys et al., 2012). Average $\triangle \mathrm{OA} / \Delta \mathrm{CO}$ from aged plumes during BORTAS was again within the range identified from 

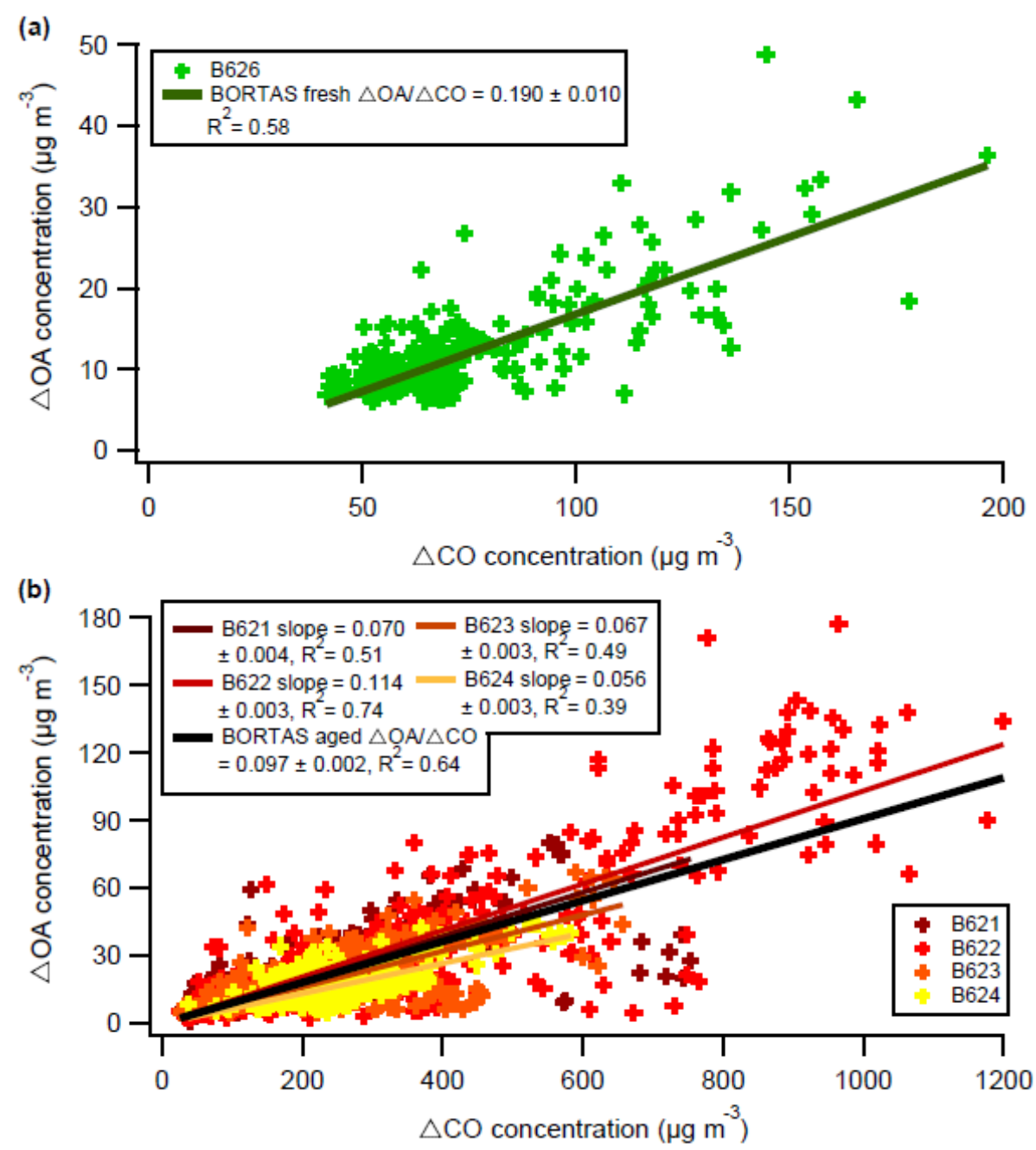

Figure 4. $\Delta \mathrm{OA}$ vs. $\Delta \mathrm{CO}$ for (a) fresh and (b) aged plumes. Coefficients are for linear regressions, from which average $\Delta \mathrm{OA} / \Delta \mathrm{CO}$ ratios are derived, with uncertainties of $\pm 1 \sigma$.

previous field observations, although with closer proximity to ratios from the lower extent of the observed range, including aged boreal forest fire plumes sampled during the Arctic Research of the Composition of the Troposphere from Aircraft and Satellites (ARCTAS) campaign (Hecobian et al., 2011). The extent of variability amongst aged emissions during ACTIVE also exceeded that observed during BORTAS, with flights throughout the former campaign sampling plumes from fires in a number of different source regions. However, analysis of ERs from vegetation fires performed under laboratory conditions during the second Fire Lab At Missoula Experiment (FLAME II) also revealed extensive variability in $\triangle \mathrm{OA} / \triangle \mathrm{CO}$ directly at source, even amongst single plant species (Jolleys et al., 2014). The single source region from which BORTAS plumes originated could therefore still be expected to give rise to significantly contrasting $\triangle \mathrm{OA} / \triangle \mathrm{CO}$, while the effects of atmospheric processing during transportation provide further perturbation of initial
ERs. Flight-average $\Delta \mathrm{OA} / \Delta \mathrm{CO}$ decreased progressively for aged emissions as the distance from source at which plumes were intercepted increased, with B622 performing a transit between Halifax and Quebec City, and B624 primarily sampling plumes over the North Atlantic off the eastern coast of Nova Scotia and Newfoundland, suggestive of OA losses during aging in these plumes from predominantly flaming sources.

\subsection{Tracers for combustion conditions}

While the evolution of $\triangle \mathrm{OA} / \triangle \mathrm{CO}$ in aging plumes would appear to be strongly influenced by the effects of atmospheric processing, source conditions remain a critical factor in controlling OA production. Contrasts in $\triangle \mathrm{OA} / \Delta \mathrm{CO}$ between fresh and aged OA are accompanied by varying properties with respect to the location and composition of plumes. Proportional contributions of OA mass fragment marker species differ between near and far-field measurements. $f_{60}$ repre- 
sents the prevalence of primary combustion products such as levoglucosan and is used as an indicator for fresh BB emissions (Schneider et al., 2006; Alfarra et al., 2007). Conversely, $f_{44}$ is associated with the $\mathrm{CO}_{2}^{+}$ion derived from more aged $\mathrm{OA}$ as hydrocarbon fragments are oxidised to form organic acids (Zhang et al., 2005; Aiken et al., 2008), although $m / z 44$ is also a constituent of fresh smoke and has been shown to be significantly elevated at source, dependent on combustion conditions (Weimer et al., 2008; Jolleys et al., 2014). While strongly associated with saturated hydrocarbon fragments, $\mathrm{m} / \mathrm{z} 43$ can also originate from oxidised compounds such as aldehydes and ketones (Alfarra et al., 2004). Large contributions of $m / z 43$ have been observed within the mass spectra of OA during the laboratory combustion of a range of biomass fuels, typically accounting for a greater proportion of total OA mass than any other detected fragments (Schneider et al., 2006). This dominance of $m / z 43$ above $m / z 44$ amongst even compounds with high oxygen contents suggests the former can be produced preferentially during the fragmentation of oxygenated molecules, and as such $f_{43}$ may prove to be an appropriate indicator of OA oxygenation at source.

Variations in the average proportions of $m / z 43,44$ and 60 in OA are widely observed between fresh and aged plumes throughout BORTAS, emphasising the contrasting properties of aerosol of different ages. Mean $f_{44}$ for B626, which comprised the only measurements of fresh OA during BORTAS, was lower than all other flights at $0.086 \pm 0.014$, with mean values for B621-B624 ranging from 0.104 to 0.139 . This trend between the near and far-field is consistent with observations of boreal forest fire plumes during ARCTAS, where $f_{44}$ was shown to increase as a function of plume transport time (Cubision et al., 2011; Hecobian et al., 2011). $f_{60}$ was also shown to decrease concurrently with increasing $f_{44}$ during ARCTAS, as a result of the oxidation of primary levoglucosan-type species with aging. However, mean $f_{60}$ for BORTAS flight B626 was also amongst the lowest throughout the campaign at $0.007 \pm 0.004$. Averages were higher for B621-B623 (0.010-0.017), although B624 provided the lowest $f_{60}$ with a mean of $0.005 \pm 0.001$.

While the higher mean $f_{44}$ observed in the far-field is likely to primarily result from more extensive oxidation of $\mathrm{OA}$ after longer periods of aging, the transition to more smouldering-dominated combustion prior to sampling of near-field plumes could also have influenced observed changes in composition. Elevated levels of $f_{60}$ in aged plumes are indicative of such an effect, as $m / z 60$ would be expected to constitute a greater proportion of fresh OA, given its typical progressive depletion through oxidation (Cubison et al., 2011). However, the relationships between $f_{44}, f_{60}$ and combustion phase are known to be complex and subject to considerable uncertainty. Weimer et al. (2008) showed $f_{60}$ to be more strongly associated with the initial flaming phase of combustion in wood burners used for domestic heating, while $f_{44}$ was higher during the later stages of the burning process when smouldering combustion dominated. These trends are attributed to changes in combustion behaviour and the consumption of different fuel components at each stage of the fire. In contrast, Gao et al. (2003) reported significantly elevated levoglucosan concentrations from smouldering fires in southern Africa, and severe depletion in emissions from flaming fires. Furthermore, Lee et al. (2010) reported overall similarity in $f_{60}$ across flaming and smouldering phases for open biomass fires carried out in a laboratory setting as part of FLAME II, while the ratio of levoglucosan to total organic carbon in filter samples from the same experiment shows a dependence on the fuel component burned (Sullivan et al., 2008). Although both $f_{44}$ and $f_{60}$ were more frequently at a maximum during flaming combustion in FLAME II burns (Jolleys et al., 2014), differences between phases were more pronounced for $f_{44}$, with less variation amongst $f_{60}$. This behaviour is expected to result from greater fire intensity during flaming combustion, although the specific effects of increased intensity on OA composition through changing oxygen availability remain unclear.

Further indication of a shift in combustion phase is provided by the differences in $f_{43}$ between fresh and aged plumes, for which respective mean values were $0.123 \pm 0.013$ and $0.088 \pm 0.012$. The low $f_{44}$ and $f_{60}$ for fresh OA suggest a dominance of smouldering fires, in agreement with the trends identified by Jolleys et al. (2014). Additional variations in plume properties appear to substantiate an association between $f_{43}$ and smouldering combustion, including the correlation between periods of high $f_{43}(>0.1)$ and low $\triangle \mathrm{BC} / \triangle \mathrm{OA}(<0.02)$ in both fresh and aged plumes, with production of $\mathrm{BC}$ expected to be at a maximum during flaming combustion (Reid and Hobbs, 1998). Absence of a prominent flaming phase close to source is also corroborated by very low $B C$ mass loadings, and reduced $\triangle B C / \triangle O A$ relative to aged emissions, while the elevated $\triangle \mathrm{OA} / \triangle \mathrm{CO}$ from these fires is consistent with the enhanced OA production typical of smouldering combustion (Yokelson et al., 1997). The lower $\Delta \mathrm{OA} / \Delta \mathrm{CO}$ and $f_{43}$, but higher $f_{44}$ and $f_{60}$, for aged OA would therefore be expected to derive from more intense, flaming-dominated combustion, which would also account for the significantly higher concentrations observed for $\triangle \mathrm{OA}, \triangle \mathrm{BC}, \triangle \mathrm{CO}$ and $\triangle \mathrm{HCN}$ despite plumes being progressively diluted over several days.

\subsection{Effects of combustion conditions on vertical distributions}

Altitudinal variations in plume composition further emphasise the importance of combustion conditions as a control on BB emissions and their propagation within the atmosphere. Profiles of aged plumes during BORTAS shown in Fig. 5 highlight the shift in properties between the upper and lower troposphere, with higher altitude plumes more typical of flaming combustion. The $\triangle \mathrm{BC} / \triangle \mathrm{OA}$ ratio is used as an indicator for the comparative contributions from flaming and 

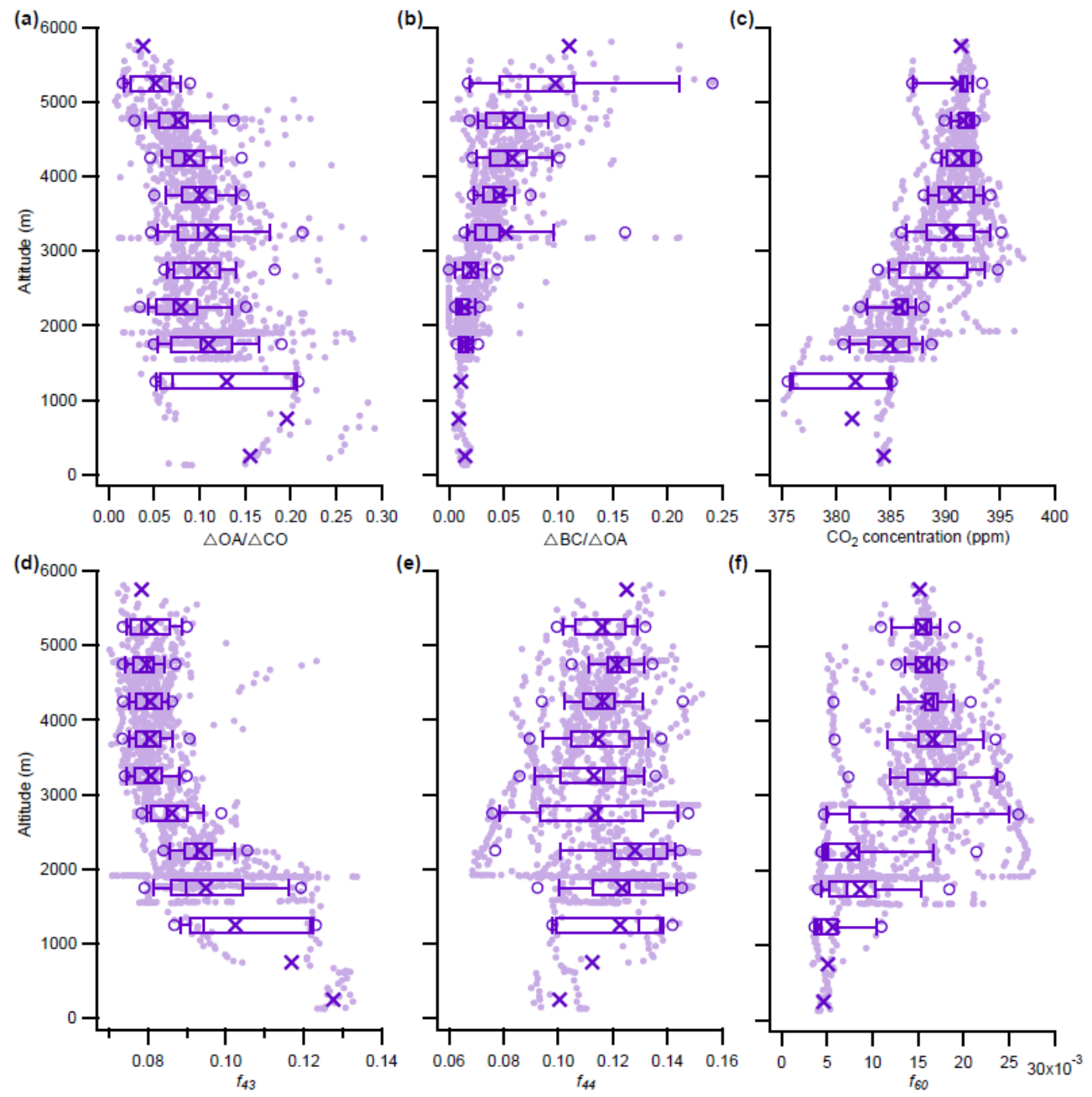

Figure 5. Vertical profiles of (a) $\Delta \mathrm{OA} / \Delta \mathrm{CO}$, (b) $\Delta \mathrm{BC} / \Delta \mathrm{OA}$, (c) $\mathrm{CO}_{2}$, (d) $f_{43}$, (e) $f_{44}$ and (f) $f_{60}$ in aged plumes. Circles represent the 5 th and 95 th percentiles, vertical lines the 10th, 25th, 50th, 75th and 90th percentile, with crosses denoting mean values in each $500 \mathrm{~m}$ altitudinal bin.

smouldering combustion phases to the overall BB particulate loading (e.g. Grieshop et al., 2009), and is shown to increase through successive $500 \mathrm{~m}$ bins from $0.015 \pm 0.003$ at $500 \mathrm{~m}$ to $0.110 \pm 0.055$ at $6000 \mathrm{~m}$, with the interquartile range increasing from $0.006(2000 \mathrm{~m})$ to $0.068(5500 \mathrm{~m})$. In contrast, $\triangle \mathrm{OA} / \triangle \mathrm{CO}$ decreases over the same range, revealing the stark contrasts in plume composition at different altitudes and the apparent influence of fire properties at source. Mean $\Delta \mathrm{OA} / \Delta \mathrm{CO}$ stands at $0.155 \pm 0.061$ and $0.196 \pm 0.103$ for the two bins closest to the surface, declining to $0.038 \pm 0.015$ at $6000 \mathrm{~m}$. The interquartile range also decreases from 0.147 to 0.044 between 1500 and $5500 \mathrm{~m}$, reflecting an overall reduction in variability with altitude.

With the exception of a few isolated points, $\Delta \mathrm{BC} / \Delta \mathrm{OA}$ only rises above 0.02 in higher plumes where $f_{43}$ is below 0.09 , and remains consistently low when $f_{43}$ is above this level (Fig. 6). This trend is in part due to the greater production of $\mathrm{BC}$ under flaming conditions, as reflected by corresponding distributions of high $\triangle \mathrm{BC}$ mass concentration, $f_{60}$ and $\mathrm{CO}_{2}$ (Fig. 6a-c). Conversely, plumes sampled at lower altitudes exhibit characteristics more strongly associated with smouldering combustion (Fig. 6d), and are comparable to fresh plumes with regards to low levels of $\Delta \mathrm{BC} / \triangle \mathrm{OA}$ and $f_{60}$, and high $f_{43}$. Weaker convection resulting from smouldering fires limits vertical transportation, retaining plumes within the boundary layer (Andreae et al., 1996; Warneke et al., 2006; Burling et al., 2011). The presence of flaming-derived emissions at higher altitudes alludes to an elevated injection height resulting from increased buoyancy and pyroconvection (Fromm et al., 2005; Damoah et al., 2006) driven by more intense fires earlier in the BORTAS campaign period (Fig. 2). A similar dependence on combustion phase has previously been observed for the altitudinal distribution of different combustion products from boreal forest fires during ARCTAS (Kondo et al., 2011). 

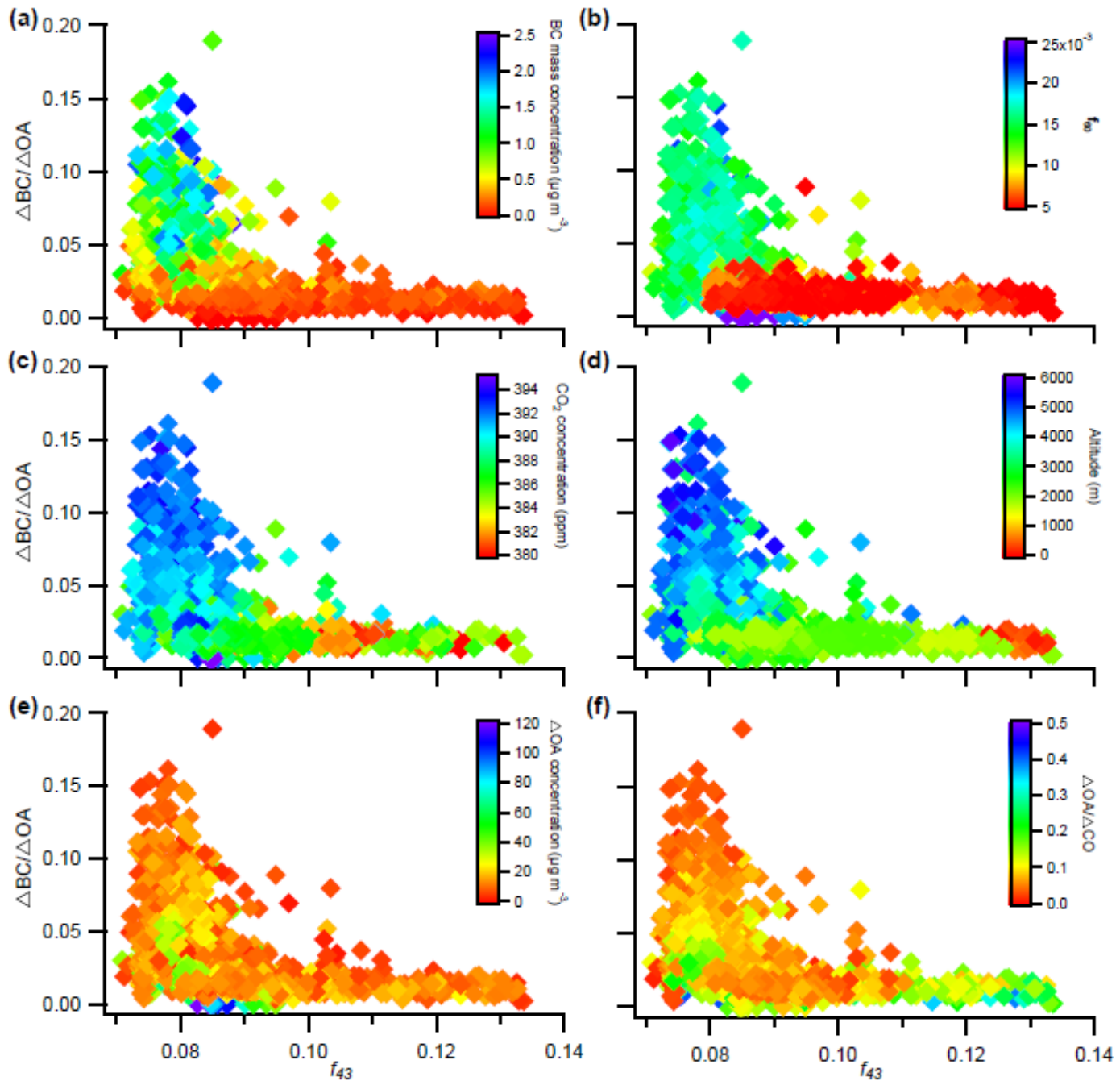

Figure 6. $\triangle \mathrm{BC} / \triangle \mathrm{OA}$ vs. $f_{43}$ for aged emissions. Data points are coloured to show relationships with (a) $\Delta \mathrm{BC}$, (b) $f_{60},(\mathbf{c}) \mathrm{CO}_{2},(\mathbf{d})$ altitude, (e) $\triangle \mathrm{OA}$ and (f) $\triangle \mathrm{OA} / \Delta \mathrm{CO}$.

The altitudinal trends identified for $\triangle \mathrm{OA} / \triangle \mathrm{CO}$ and $\Delta \mathrm{BC} / \Delta \mathrm{OA}$ also show broad agreement with those of $f_{43}$ and $f_{60}$ respectively, with mean values for the former decreasing from $0.128 \pm 0.006$ to $0.078 \pm 0.003$ and latter increasing from $0.005 \pm 0.001$ to $0.015 \pm 0.002$. The directly opposing profiles of $f_{43}$ and $\mathrm{CO}_{2}$ (Fig. 5c-d), along with the correlation of increased $f_{60}$ with $\mathrm{CO}_{2}$ and $\triangle \mathrm{BC}$ mass at high altitudes (Fig. 7h-i), further underline the importance of initial combustion conditions for aged emissions. Minimum $\mathrm{CO}_{2}$ concentrations within aged plumes were around $375 \mathrm{ppm}$, representing a minimal elevation above typical background levels for boreal Canadian forest environments (Vay et al., 2011, Higuchi et al., 2003). Although the distribution of $\mathrm{CO}_{2}$ clearly reflects the influence of the biosphere closer to the surface through uptake in photosynthesis, expected source profiles also appear to be largely conserved, further corroborated by the sustained correlation between pe- riods of high $f_{43}$ and low $\mathrm{CO}_{2}$, and vice versa, relative to levels throughout the rest of the aged plumes.

\subsection{Aging as a driver for plume variability}

Despite the apparent influence of combustion conditions on the vertical distribution and composition of aged emissions, the effects of transformations associated with atmospheric processing cannot be entirely discounted. Certain contrasting properties between emissions of different ages could also be less dependent on source conditions and more strongly influenced by processing throughout plume evolution. Differences between fresh and aged plumes in the respective relationships of total $\triangle \mathrm{OA}$ loadings, and those normalised to $\Delta \mathrm{CO}$, with a number of tracers highlight the combined effects of source conditions and processing, and their changing influence with aging. Both $\triangle \mathrm{OA}$ and $\triangle \mathrm{CO}$ concentrations show a negative correlation with $f_{44}$ (e.g. Fig. $7 \mathrm{a}-\mathrm{b}$ ) and 

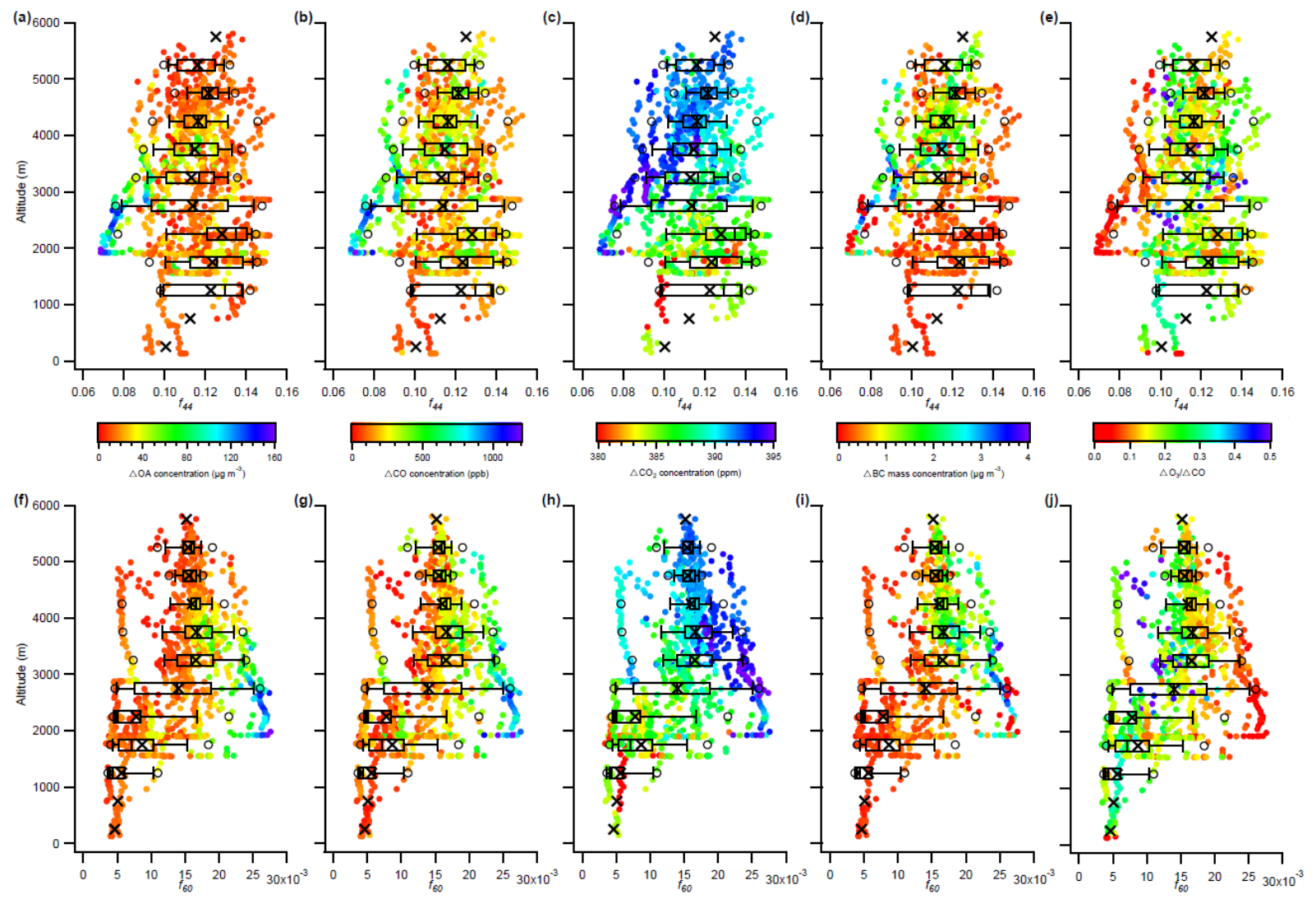

Figure 7. Vertical profiles of (a-e) $f_{44}$ and (f-j) $f_{60}$ in aged plumes. Data points are coloured by $(\mathbf{a}+\mathbf{f}) \Delta \mathrm{OA},(\mathbf{b}+\mathbf{g}) \Delta \mathrm{CO},(\mathbf{c}+\mathbf{h}) \mathrm{CO}_{2}$, $(\mathbf{d}+\mathbf{i}) \Delta \mathrm{BC}$ and $(\mathbf{e}+\mathbf{j}) \Delta \mathrm{O}_{3} / \Delta \mathrm{CO}$. Circles represent the 5th and 95th percentiles, vertical lines the 10th, 25th, 50th, 75th and 90th percentile, with crosses denoting mean values in each $500 \mathrm{~m}$ altitudinal bin.

positive correlation with $f_{60}$ (e.g. Fig. $7 \mathrm{f}-\mathrm{g}$ ). Furthermore, when binning concentrations by $f_{44}$, maximum binned $\Delta \mathrm{OA}$ and $\Delta \mathrm{CO}$ both coincide with minimum $f_{44}$ and vice versa. These overriding trends remain consistent for emissions of all ages, although the nature of the relationship changes in each case. Linear relationships appear consistently for $\triangle \mathrm{OA}$ $\left(R^{2}=0.51\right.$ and 0.80 with $f_{44}$ and $f_{60}$ respectively) and $\Delta \mathrm{CO}$ $\left(R^{2}=0.23\right.$ and 0.49$)$ in fresh emissions. The same relationships also persist to an extent for $\triangle \mathrm{OA} / \triangle \mathrm{CO}$ in fresh plumes $\left(R^{2}=0.42\right.$ and 0.47$)$. However, at a greater distance from source, correlations for $\triangle \mathrm{OA}$ and $\triangle \mathrm{CO}$ are consistently below 0.3 , while there is no relationship between $\Delta \mathrm{OA} / \Delta \mathrm{CO}$ and either $f_{44}$ or $f_{60}$.

In addition to providing a tracer for source profiles in aged BB emissions, $\triangle \mathrm{BC} / \triangle \mathrm{OA}$ can also be used as an indicator for OA processing. Observations of increasing $\triangle \mathrm{BC} / \triangle \mathrm{OA}$ with aging have previously been attributed to the loss of OA mass through evaporation (Liousse et al., 1995). Similar behaviour has also been proposed as a possible cause of the overall reduction in $\triangle \mathrm{OA} / \triangle \mathrm{CO}$ between $\mathrm{BB}$ plumes in the near and far-field throughout several campaigns across different global regions (Jolleys et al., 2012). Any decrease in $\triangle \mathrm{BC} / \triangle \mathrm{OA}$ could therefore be considered a product, to a certain degree, of the addition of secondary organic mass from either the processing of BBOA or external sources. Measurements performed at lower altitudes $(<2000 \mathrm{~m})$ during flights B621 and B622 provide possible evidence to support such an effect. Both $\triangle \mathrm{BC}$ mass and $f_{60}$ remain low during these periods, at less than $0.5 \mu \mathrm{g} \mathrm{m}^{-3}$ and 0.01 respectively, consistent with wider observations of smouldering fire emissions at low altitude during BORTAS. However, $\triangle \mathrm{CO}$ concentrations are also diminished and consistently below $100 \mathrm{ppb}$, relative to an average of $200 \mathrm{ppb}$ for aged plumes, while $\triangle \mathrm{OA}$ concentrations are comparable to levels in higher altitude, flaming-type plumes $\left(\sim 20 \mu \mathrm{g} \mathrm{m}^{-3}\right)$. These trends, which diverge from the expected characteristics for emissions of this origin, are further compounded by high $\Delta \mathrm{O}_{3} / \Delta \mathrm{CO}(>0.2)$, indicative of an elevated level of oxygenation and photochemical activity (Mason et al., 2001; Parrington et al., 2013). Formation of SOA from biogenic precursors has previously been observed in the forests of Ontario (Slowik et al., 2010). These SOA events were also characterised by $\triangle \mathrm{OA} / \triangle \mathrm{CO}$ levels far in excess of those derived for $\mathrm{BB}$ emissions during the same study. In accordance with this trend, $\triangle \mathrm{OA} / \triangle \mathrm{CO}$ within the low altitude plumes in B621 and B622 were consistently above the average for 
aged emissions (0.097), reaching as high as $\sim 0.4$. There is subsequently considerable evidence to support biogenic SOA as a potential contributor to the OA burden during BORTAS, which could provide further enhancement of $\triangle \mathrm{OA} / \Delta \mathrm{CO}$ as demonstrated by the Slowik et al. (2010) Ontario study. Whilst the further properties of aged plumes discussed here would suggest this effect is isolated and limited in its overall impact, it presents a further source of uncertainty for any attempts to develop parameterisations for the contribution of forest fires to regional and global OA budgets.

Although $f_{60}$ displays a level of consistency with flaming combustion products in upper troposphere plumes during BORTAS, and increases on average with increasing altitude, further trends oppose the expected relationships for different combustion phases. Maximum concentrations of $\triangle \mathrm{OA}$, $\triangle \mathrm{BC}, \triangle \mathrm{CO}$ and $\mathrm{CO}_{2}$ all coincide with high $f_{60}(0.025-$ 0.300 ) and show a reduction as $f_{60}$ decreases (Fig. $7 \mathrm{f}-\mathrm{i}$ ). Overall correlations between each species and $f_{60}$ are all positive, albeit with varying fit coefficients. $R^{2}$ values were highest for $\mathrm{CO}_{2}$ and $\triangle \mathrm{BC}(0.52$ and 0.47$)$, reflecting their stronger associations with flaming combustion (Crutzen and Andreae, 1990; Reid et al., 2005). Correlations with $\triangle \mathrm{OA}$ and $\Delta \mathrm{CO}$ were weaker $\left(R^{2}=0.28\right.$ and 0.23$)$, as would be expected given production of each is greatest during the smouldering phase (Ferek et al., 1998; Andreae and Merlet, 2001; Gao et al., 2003). While trends with $\Delta \mathrm{O}_{3} / \Delta \mathrm{CO}$ show $f_{60}$ to decrease with aging (Fig. $7 \mathrm{j}$ ), the underlying relationships identified with all other species suggest $f_{60}$ may prove to be a more resilient tracer for overall plume intensity rather than combustion conditions at long aging times. However, Petzold et al. (2007) demonstrated export efficiencies of up to $90 \%$ for $\mathrm{BC}$ following intercontinental transport of boreal forest fire plumes. In the absence of significant removal through wet deposition, $\triangle \mathrm{BC} / \triangle \mathrm{CO}$ in plumes encountered at altitudes above $4 \mathrm{~km}$ remained consistent with typical source values, indicating that mixing of emissions can be suppressed where fire intensity is sufficient to generate elevated injection heights. Conversely, the weaker convection associated with smouldering combustion may lead to emissions being retained within the boundary layer, contributing to the typically higher levels of $\Delta \mathrm{OA} / \Delta \mathrm{CO}$ and $f_{43}$ at low altitudes.

\subsection{Tracer evolution during BORTAS}

The progression from $f_{60}$ to $f_{44}$ can provide a useful metric to assess the evolution of OA composition with aging. Figure 8 shows the nature of this progression for both fresh and aged OA, together with further trends with several additional parameters. A strong linear relationship $\left(R^{2}=0.72\right)$ is identified for emissions close to source. However, these observations comprised measurements of three separate periods of flight B626, and reveal a clear discrepancy for one of these periods. Measurements performed further to the east of the source region, on a transect from approximately $52.3^{\circ} \mathrm{N}$, $90.0^{\circ} \mathrm{W}$ to $52.8^{\circ} \mathrm{N}, 91.3^{\circ} \mathrm{W}$ (a "downwind" plume) yielded higher $f_{44}$ than any other fresh plumes, with $f_{60}$ not exceeding 0.045 . The two remaining sets of plumes ("source" plumes) were both encountered within a region where active fires were present at around $52.4-52.8^{\circ} \mathrm{N}, 93.0-93.7^{\circ} \mathrm{W}$. Despite sampling taking place roughly two hours apart, and over a slightly different geographical extent, the $f_{44} / f_{60}$ relationship remains highly consistent across all "source" plumes, with an $R^{2}$ of 0.82 . The higher levels of $f_{44}$ and absence of a trend with $f_{60}$ in the "downwind" plume indicate OA is more heavily oxidised than in the fresher "source" plumes. This contrast in oxygenation is linked to other changes between plumes, including apparent photochemical age, which in this instance is represented by the $-\log \left(\mathrm{NO}_{\mathrm{x}} / \mathrm{NO}_{\mathrm{y}}\right)$ ratio (Kleinman et al., 2008; DeCarlo et al., 2008). Levels of the ratio are significantly elevated in the "downwind" plume from B626 (Fig. 8f, left panel), with an average of $1.45 \pm 0.43$, exceeding the mean value of $1.09 \pm 0.29$ for highly aged plumes sampled during flights B621-B624. $\mathrm{CO}_{2}$ concentrations during this period are also higher than for the remainder of B626 (Fig. 8b, left panel), with an average of $378.6 \pm 0.6 \mathrm{ppm}$ compared to $375.0 \pm 1.3 \mathrm{ppm}$ closer to source. The $-\log \left(\mathrm{NO}_{\mathrm{x}} / \mathrm{NO}_{\mathrm{y}}\right)$ photochemical clock is also shown to increase throughout "source" plumes, with $f_{44}$ and $f_{60}$ changing in a manner consistent with the increasing oxidation of $\mathrm{OA}$, and is further corroborated by a trend of increasing $\Delta \mathrm{O}_{3} / \Delta \mathrm{CO}$ (Fig. 8e, left panel). However, these changes also coincide with a trend of decreasing $\triangle \mathrm{OA} / \triangle \mathrm{CO}$ (Fig. 8c, left panel), belying the expected addition of $\mathrm{OA}$ mass resulting from increasing oxygenation as semivolatile products condense to the particle phase. Average $\triangle \mathrm{OA} / \triangle \mathrm{CO}$ is similar for the two "source" plumes $(0.165 \pm 0.042$ and $0.180 \pm 0.045)$, but is lower in the more photochemically aged "downwind" plume $(0.114 \pm 0.015)$. It is difficult to speculate on the significance of any link between a higher rate of oxidation and an overall reduction in $\triangle \mathrm{OA} / \triangle \mathrm{CO}$ given the continuing uncertainty regarding the processes affecting $\mathrm{OA}$ in aging BB plumes. Yokelson et al. (2009) reported that $\Delta \mathrm{OA} / \Delta \mathrm{CO}$ increased by a factor of 2.3 over a period of $1.4 \mathrm{~h}$ for plumes from fires in the Yucatán region of Mexico, coinciding with a comparably high $f_{44} / f_{60}$ gradient to that in the "downwind" section of B626. Conversely, an increase in $f_{44}$ has also been shown in conjunction with stable or even decreasing levels of $\triangle \mathrm{OA} / \triangle \mathrm{CO}$ (Capes et al., 2008; Cubison et al., 2011; Akagi et al., 2012; Jolleys et al., 2012), suggesting OA loss through evaporation has an equally important effect throughout plume evolution.

Linear relationships between $f_{44}$ and $f_{60}$ are weaker for more aged plumes sampled at a greater distance downwind, with an overall $R^{2}$ value for all plumes of 0.44 and individual flights ranging from 0.01 (B624) to 0.32 (B622). The overall decline of $f_{60}$ again appears to be strongly influenced by distance from the source region and the physical age of plumes, decreasing from a maximum of $\sim 0.027$ in B622 to a minimum of $\sim 0.004$ in B624. An effect of dilution is evident, given the concurrent reduction in both $\triangle \mathrm{CO}$ 

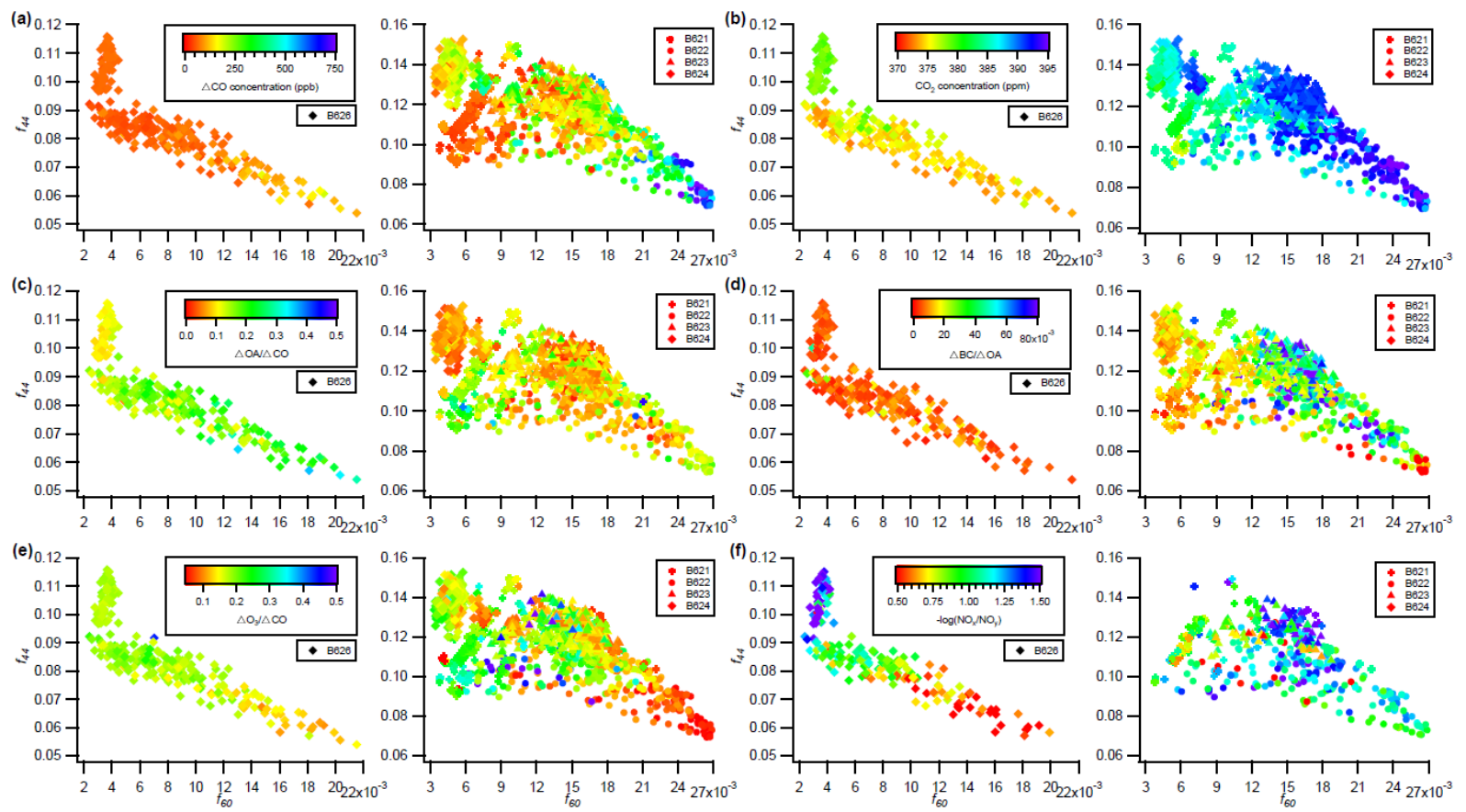

Figure 8. $f_{44}$ vs. $f_{60}$ with data points coloured by (a) $\Delta \mathrm{CO}$, (b) $\mathrm{CO}_{2}$, (c) $\Delta \mathrm{OA} / \Delta \mathrm{CO}$, (d) $\Delta \mathrm{BC} / \Delta \mathrm{OA},(\mathbf{e}) \Delta \mathrm{O}_{3} / \Delta \mathrm{CO}$ and (f) $-\log \left(\mathrm{NO}_{\mathrm{x}} / \mathrm{NO}_{\mathrm{y}}\right)$. Data from fresh and aged plumes are shown on the left and right hand side of each panel, respectively.

and $\mathrm{CO}_{2}$ with decreasing $f_{60}$ and increasing $f_{44}$ (Fig. 8a$\mathrm{b}$, right panels). $\Delta \mathrm{O}_{3} / \Delta \mathrm{CO}$ shows the reverse progression, increasing with the oxygenation of OA (Fig. 8e, right panel), while $-\log \left(\mathrm{NO}_{\mathrm{x}} / \mathrm{NO}_{\mathrm{y}}\right)$ does not exhibit the strong trend observed for near-field measurements but is typically higher and reflects longer aging times (Fig. 8f). However, $-\log \left(\mathrm{NO}_{\mathrm{x}} / \mathrm{NO}_{\mathrm{y}}\right)$ ratios were highest on average for the "downwind" plume in B626, which did not provide any significant indication of net addition of OA mass. While the highest average $\triangle \mathrm{OA} / \triangle \mathrm{CO}$ ratio for an individual plume throughout the entirety of BORTAS was derived for one of the "source" plumes during B626, two aged plumes from B622 exhibited average $\triangle \mathrm{OA} / \triangle \mathrm{CO}$ of a similar magnitude $(0.120 \pm 0.080$ and $0.119 \pm 0.042)$, with each plume representing a different region of $f_{44} / f_{60}$ space.

The contrasting behaviours of various tracers throughout fresh and aged plumes highlights the different ways in which these properties can be used to evaluate influences on BBOA evolution. With regards to $f_{44}$, the consistently higher values observed in aged plumes, and the strong trends identified with indicators of photochemical aging such as $-\log \left(\mathrm{NO}_{\mathrm{x}} / \mathrm{NO}_{\mathrm{y}}\right.$ ) and $\Delta \mathrm{O}_{3} / \Delta \mathrm{CO}$ close to source (Fig. 8e$\mathrm{f}$, left panels), substantiate its use as a tracer for OA aging. Although $f_{60}$ exhibits the same clear relationship with $-\log \left(\mathrm{NO}_{\mathrm{x}} / \mathrm{NO}_{\mathrm{y}}\right)$ and $\Delta \mathrm{O}_{3} / \Delta \mathrm{CO}$ in fresh plumes, albeit reversed and decreasing with aging, values are higher on average amongst aged plumes. Given the overall trend of increasing $f_{44}$ with decreasing $f_{60}$ remains for aged $\mathrm{OA}$, the longer periods of aging to which these plumes have been exposed would be expected to bring about a more extensive reduction in the latter tracer. The elevation in $f_{60}$ relative to fresh plumes would therefore seem to stem from the contrasting dominant combustion phases associated with plumes of different ages, and the persistence of high levels in flaming-derived OA at greater altitudes. In contrast, $f_{43}$ shows an overall reduction with aging, with mean values of $0.123 \pm 0.013$ and $0.088 \pm 0.012$ for near and far-field plumes respectively, consistent with the oxidation of primary OA components over time. However, overall trends with $-\log \left(\mathrm{NO}_{\mathrm{x}} / \mathrm{NO}_{\mathrm{y}}\right)$ and $\Delta \mathrm{O}_{3} / \Delta \mathrm{CO}$ in fresh plumes are generally positive, albeit with fairly weak correlation coefficients $\left(R^{2}=0.12\right.$ and 0.34$)$, resulting in $f_{43}$ peaking at greater photochemical ages. This relationship contradicts that which would be expected in aging OA (Ng et al., 2010; Morgan et al., 2010), and suggests additional factors may be contributing to the observed variability in $f_{43}$. However, fragmentation of oxygenated aldehyde and ketone molecules has been shown to produce elevated levels of $f_{43}$ relative to $f_{44}$ in BB emissions (Schneider et al., 2006), suggesting possible contributions from secondary formation. Values of $f_{43}$ in fresh OA are almost entirely greater than 0.1 , while this threshold is most frequently exceeded amongst aged $\mathrm{OA}$ in plumes below around $3000 \mathrm{~m}$ (Fig. 5d). These lower altitude plumes exhibit the same low $\triangle \mathrm{BC} / \triangle \mathrm{OA}$ levels as identified close to source $(<0.02)$, in contrast to the greater range in $\triangle \mathrm{BC} / \triangle \mathrm{OA}$ (up to 0.15) coinciding with lower $f_{43}$ (Fig. 6). Differing distributions of $f_{43}$ in aged plumes, and the prescribed similarities with near-field observations, may reflect 
an influence of changing combustion conditions, with $f_{43}$ seemingly more prominent in OA from smouldering fires. As a result, $f_{43}$ may prove to be a more suitable tracer for source conditions rather than the effects of aging, although comparison between different combustion phases at source would be required in order to fully constrain any such relationship.

\subsection{Campaign intercomparison and evaluation of $f_{44}$ and $f_{60}$ tracers}

The progression of $f_{44}$ and $f_{60}$ throughout BORTAS shows a number of similarities with observations from other field campaigns and laboratory experiments. Distributions for fresh and aged emissions from BORTAS and montane forest fires during the Megacities Initiative: Local and Global Research Observations (MILAGRO) campaign are presented in Fig. 9, along with data from numerous plumes measured during ARCTAS-B. Data are also shown for the combustion of boreal forest plant species under laboratory conditions as part of FLAME II. Similar trends in $f_{44} / f_{60}$ for fresh and aged emissions are identified for BORTAS and MILAGRO, with average $f_{44}$ increasing with aging in both cases. A significant contrast is also evident in the distributions of $f_{60}$, which is higher on average for fresh plumes in MILAGRO and aged plumes in BORTAS, possibly as a result of the reduced intensity of fires sampled close to source. Average $\triangle \mathrm{OA} / \triangle \mathrm{CO}$ is again lower for the aged fraction in MILAGRO, decreasing from $0.051 \pm 0.001$ in fresh plumes to $0.041 \pm 0.001$ (Jolleys et al., 2012), consistent with a loss of OA. The lower magnitude of these ratios is likely to be a consequence of different fuel properties and resulting combustion conditions, as strongly flaming grass fires are expected to have made a significant contribution to smoke plumes sampled at the Paso de Cortes measurement site (Jolleys et al., 2014). Figure 9 also emphasises the differences in emissions from boreal forest fires during ARCTAS-B and BORTAS. Plumes encountered close to source in each campaign exhibit contrasting levels of $f_{60}$, reflecting the dominance of different combustion phases in each set of measurements. Unlike the heavily smouldering fires sampled in flight B626, the plume from a fire at Lake McKay in north-western Saskatchewan was produced by highly intense, flaming fires (Cubison et al., 2011). The Lake McKay fires subsequently yielded higher $f_{60}$ than was observed for any BORTAS plumes, peaking at around 0.05. As the Lake McKay plume was tracked downwind, $f_{44}$ increased to $\sim 0.12$, comparable to the upper extent for fresh plumes in BORTAS. Although $f_{60}$ decreased to $\sim 0.015$, this level remained above the majority of the distribution from BORTAS. Similarly high levels of $f_{60}$ were observed for black spruce fires during FLAME II. However, $f_{44}$ from these burns was generally exceptionally low, as would be expected given the direct measurement at source and lack of aging. Higher $f_{44}$ comparable to the range identified in ambient emissions did occur in chamber fires for plant species representing environments other than boreal forests, with average

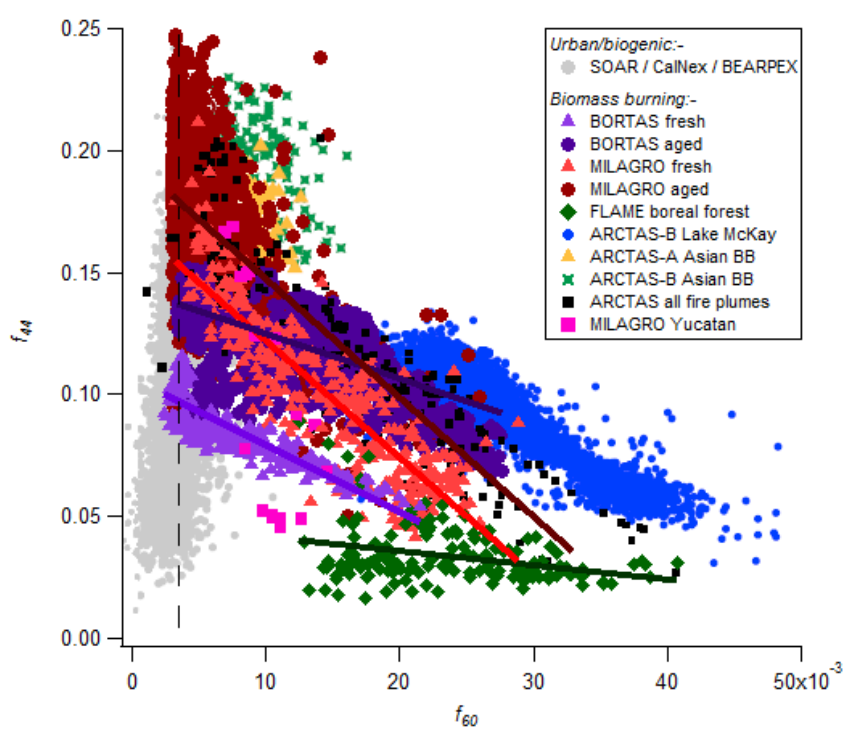

Figure 9. Synthesis of $f_{44}$ vs. $f_{60}$ from a range of ambient and laboratory measurements of BBOA, along with data from non-BB sources. The specified background $f_{60}$ value of 0.003 used to identify BB influences is shown as the dashed vertical line. Coloured lines denote linear regressions for corresponding data sets. Adapted from Cubison et al. (2011).

values particularly high for chaparral fuels. Montane forest fuels, which like the boreal equivalent comprised samples of coniferous species, also yielded $f_{44}$ up to $\sim 0.15$, although such fires largely involved drier, woody plant material leading to more flaming-dominated combustion (Jolleys et al., 2014).

The different $f_{44}$ and $f_{60}$ regimes in ambient and chamber fires, and their conflicting relationships with combustion phases, suggest their use as tracers for processing of BBOA is highly dependent on both fire properties and experimental conditions. Throughout FLAME II, $f_{44}$ was shown to be more strongly associated with flaming combustion, as increased intensity and turbulent mixing enhanced the supply of oxygen to fires. In contrast, the rapid increase of $f_{44}$ in fresh OA from smouldering fires during BORTAS, to levels comparable to more extensively aged plumes, indicate that $f_{44}$ is strongly influenced by post-emission processing under ambient conditions. Relationships with $f_{60}$ are more consistent, being higher on average more frequently for flamingdominated fires under laboratory conditions, and showing a stronger association with seemingly flaming-derived aged emissions during BORTAS. Probability density functions (PDFs) for $f_{44}$ and $f_{60}$ in fresh and aged emissions from BORTAS, along with source emissions from fires involving boreal and montane forest fuels during FLAME II, are shown in Fig. 10. The clear separation in $f_{44}$ distributions between chamber and ambient measurements reflects the role of aging in determining the level of oxidation in BBOA, as further evidenced by the enhancement in plumes in the far- 


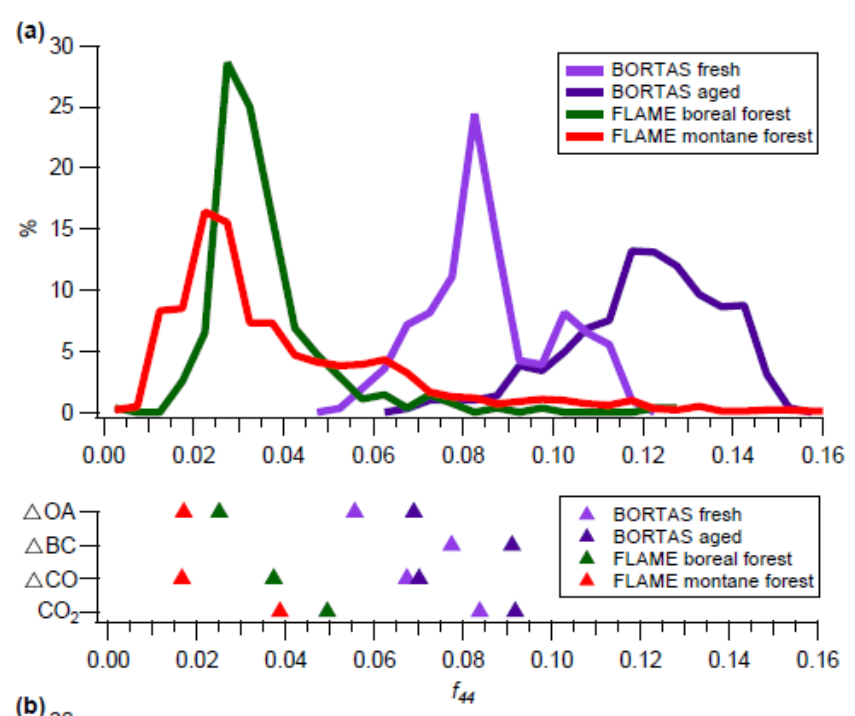

(b)
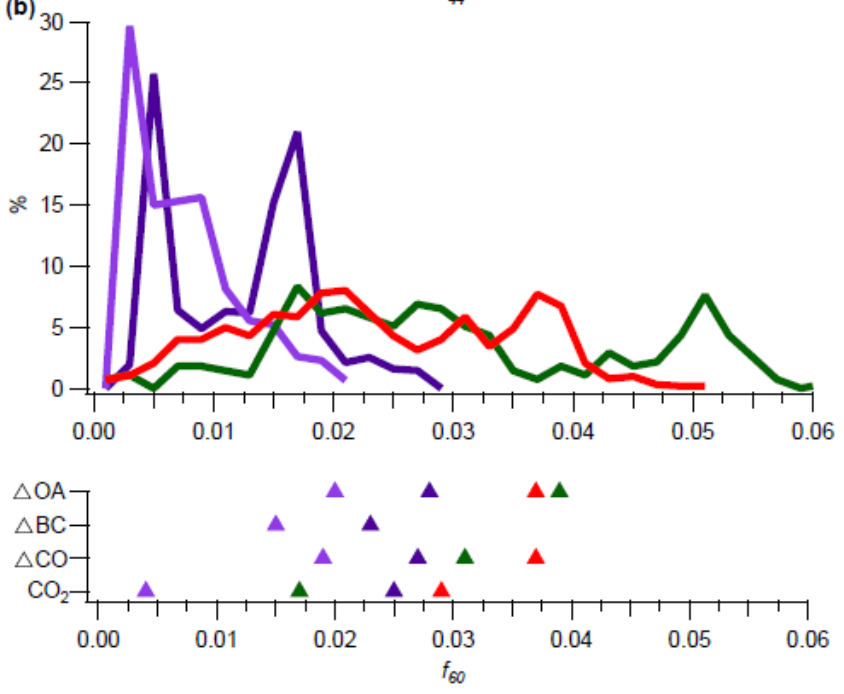

Figure 10. Probability density functions for (a) $f_{44}$ and (b) $f_{60}$ from a range of ambient and laboratory BB measurements. Also shown in the lower sections of each panel are the $f_{44}$ and $f_{60}$ values corresponding to maximum concentrations of $\triangle \mathrm{OA}, \triangle \mathrm{BC}, \triangle \mathrm{CO}$ and $\mathrm{CO}_{2}\left(\Delta \mathrm{CO}_{2}\right.$ during FLAME).

field above those at source. However, the trend of increasing $f_{44}$ in fresh plumes suggests that this processing can occur over very short timescales under certain atmospheric conditions. Rapid oxidation of BB smoke plumes has previously been inferred from the addition of secondary OA mass within $\sim 1 \mathrm{~h}$ of emission (Gao et al., 2003; Yokelson et al., 2009), corroborating the BORTAS trend. Values of $f_{44}$ coinciding with peak concentrations for a number of combustion products are also shown in Fig. 10. These peak concentrations show a good agreement with prescribed combustion phase relationships for FLAME II data, where $\Delta \mathrm{CO}_{2}$ reaches a maximum when $f_{44}$ is higher, and hence combustion more flaming-dominated, while $\Delta \mathrm{OA}$ and $\Delta \mathrm{CO}$ peak at a lower $f_{44}$. The same trends are also observed through- out BORTAS, with peak concentrations for $\mathrm{CO}_{2}$ and $\triangle \mathrm{BC}$ coinciding with higher levels of $f_{44}$ than those of $\Delta \mathrm{CO}$ or $\triangle \mathrm{OA}$. PDFs for $f_{60}$ exhibit the same trend amongst ambient plumes, shifting to higher values with aging. Distributions are also broadened for emissions from chamber burns, for which levoglucosan-type species constitute a larger proportion of the total OA mass. The very low peak for near-field BORTAS plumes could be influenced by both the absence of a significant flaming phase and subsequent oxidation of primary OA (Cubison et al., 2011), contributing to the increase in $f_{44}$. The variable gradients for $f_{44} / f_{60}$ regressions (Fig. 9) indicate a slower rate of decay for levoglucosan-type OA in aged BORTAS plumes compared to their equivalents from MILAGRO. Furthermore, mean $f_{60}$ in aged MILAGRO plumes $(0.006 \pm 0.003)$ was lower than in fresh plumes $(0.018 \pm 0.006)$, while the opposite was true for BORTAS plumes $(0.012 \pm 0.005$ and $0.007 \pm 0.004$ respectively). As such, the slower decline of $f_{60}$ and potential influences from more strongly flaming combustion may contribute towards the observed enhancement in aged BORTAS plumes, while a faster rate of oxidation and largely smouldering fires reduce levels closer to source.

\section{Conclusions}

Smoke plumes from Canadian boreal forest fires have been shown to exhibit highly variable properties over a range of ages and combustion phases. Average $\triangle \mathrm{OA} / \triangle \mathrm{CO}$ in 3 plumes sampled close to source $(0.190 \pm 0.010)$ exceed ratios in the far-field from 23 interceptions $(0.056 \pm 0.003$ to $0.114 \pm 0.003$ ), reaffirming an absence of significant net SOA formation for aging BB emissions, at least to an extent that provides an elevation above initial OA production at source. While contrasting aging behaviours and significant SOA formation have been identified in some studies, an absence of increasing $\triangle \mathrm{OA} / \triangle \mathrm{CO}$ has been observed in several previous $\mathrm{BB}$ assessments. The trend of decreasing $\triangle \mathrm{OA} / \triangle \mathrm{CO}$ with increasing distance from source in BORTAS further emphasises the importance of source conditions for aging plumes. High levels of typical flaming combustion products were identified in highly aged plumes following transportation over a period of several days. Enhancements in $\triangle \mathrm{BC} / \triangle \mathrm{OA}$ and $f_{60}$ were most prominent within the free troposphere, typically displaying an overall increase with altitude, while aged OA sampled within the boundary layer showed stronger evidence for production by smouldering combustion.

Aging of BBOA during BORTAS has been extensively evaluated using the key tracers $f_{44}$ and $f_{60}$ from the AMS mass spectrum. An enhancement in $f_{44}$ was determined for far-field plumes, where the mean value of $0.121 \pm 0.016$ significantly exceeded that in the nearfield $(0.086 \pm 0.014)$. Similarly, $f_{60}$ remained higher in aged plumes $(0.012 \pm 0.005)$ than those close to source 
$(0.007 \pm 0.004)$, in spite of the concurrent increase in oxygenation and expected processing of primary OA components. These trends highlight the importance of both source conditions and processing for OA composition in BB plumes. While the influence of combustion phase on $f_{44}$ remains highly uncertain given contrasting relationships with smouldering and flaming combustion reported in different studies, increases observed close to source suggest oxidation can occur over very short timescales after emission. This rapid processing is further corroborated by concurrent increases in photochemical tracers such as $\Delta \mathrm{O}_{3} / \Delta \mathrm{CO}$ and $-\log \left(\mathrm{NO}_{\mathrm{x}} / \mathrm{NO}_{\mathrm{y}}\right)$ ratios in plumes sampled near to source. The increasing oxygenation of BBOA is not accompanied by an increase in $\triangle \mathrm{OA} / \triangle \mathrm{CO}$, which shows no significant change with $\Delta \mathrm{O}_{3} / \Delta \mathrm{CO}$ and decreases on average with $-\log \left(\mathrm{NO}_{\mathrm{x}} / \mathrm{NO}_{\mathrm{y}}\right)$ over short aging times. A lack of $\triangle \mathrm{OA} / \triangle \mathrm{CO}$ enhancement irrespective of evidence for wider transformations therefore further substantiates the impact of OA losses in these aging BB plumes.

Presenting the changing composition of BBOA in $f_{44} / f_{60}$ space reveals a consistent progression from high $f_{60}$ to high $f_{44}$ as primary levoglucosan-like species are lost through oxidation. Similar transitions occur across multiple data sets encompassing smoke plumes of varying origins and ages, although the gradients and extents of distributions show some variability between campaigns. Levels of $f_{44}$ are also comparatively depleted in chamber burns of boreal forest fuels. The absence of aging and a strong association with flaming combustion, and hence oxygen supply through entrainment, in these experiments denote alternative tracer functions under laboratory and ambient conditions. While $f_{44}$ can act as an indicator for oxygenation through combustion processes in chamber experiments, the influence of aging is likely to limit such application for ambient emissions. However, $f_{60}$ has been shown to act as a long-lived tracer for BB emissions, despite evidence for an overall reduction with increasing $f_{44}$.

Analysis of measurements performed during the BORTAS campaign has provided further insight to the variability associated with BB emissions and the processes affecting changes in BBOA loadings and composition over time. However, there remains considerable uncertainty regarding the main drivers of OA processing. While data from BORTAS provide evidence for the influence of a range of source and aging processes, the extents of any effects on aging BBOA are unclear, particularly with regard to their consistency across different environments and fire types. Key trends identified in this analysis, such as the comparatively lower levels of $f_{60}$ close to source, contradict previous findings and highlight the lack of consistency prevalent amongst many aspects of investigations focusing on $\mathrm{BB}$ emissions. Further research specifically targeting these areas of uncertainty is therefore essential in order to understand the cause of these disparities and provide more reliable parameterisations of $\mathrm{BB}$ contributions to the atmospheric aerosol burden.
Acknowledgements. The authors would like to acknowledge financial support from the United Kingdom Natural Environment Research Council (NERC) under grant number NE/F017391/1, and thank all those involved in the BORTAS project. Airborne data was obtained using the FAAM BAe-146 Atmospheric Research Aircraft (ARA) operated by Directflight Ltd (DFL) and managed by the Facility for Airborne Atmospheric Measurements (FAAM), which is a joint entity of NERC and the UK Meteorological Office. M. D. Jolleys was supported by a NERC studentship NE/H525162/1. P. I. Palmer also acknowledges support from the Leverhulme Trust.

Edited by: S. Matthiesen

\section{References}

Aiken, A. C., DeCarlo, P. F., Kroll, J. H., Worsnop, D. R., Huffman, J. A., Docherty, K. S., Ulbrich, I. M., Mohr, C., Kimmel, J. R., Sueper, D., Sun, Y., Zhang, Q., Trimborn, A., Northway, M., Ziemann, P. J., Canagaratna, M. R., Onasch, T. B., Alfarra, M. R., Prevot, A. S. H., Dommen, J., Duplissy, J., Metzger, A., Baltensperger, U., and Jimenez, J. L.: O/C and OM/OC ratios of primary, secondary, and ambient organic aerosols with high-resolution time-of-flight aerosol mass spectrometry, Environ. Sci. Tech., 42, 44780-4485, doi:10.1021/es703009q, 2008.

Aiken, A. C., Salcedo, D., Cubison, M. J., Huffman, J. A., DeCarlo, P. F., Ulbrich, I. M., Docherty, K. S., Sueper, D., Kimmel, J. R., Worsnop, D. R., Trimborn, A., Northway, M., Stone, E. A., Schauer, J. J., Volkamer, R. M., Fortner, E., de Foy, B., Wang, J., Laskin, A., Shutthanandan, V., Zheng, J., Zhang, R., Gaffney, J., Marley, N. A., Paredes-Miranda, G., Arnott, W. P., Molina, L. T., Sosa, G., and Jimenez, J. L.: Mexico City aerosol analysis during MILAGRO using high resolution aerosol mass spectrometry at the urban supersite (T0) - Part 1: Fine particle composition and organic source apportionment, Atmos. Chem. Phys., 9, 6633-6653, doi:10.5194/acp-9-6633-2009, 2009.

Akagi, S. K., Yokelson, R. J., Wiedinmyer, C., Alvarado, M. J., Reid, J. S., Karl, T., Crounse, J. D., and Wennberg, P. O.: Emission factors for open and domestic biomass burning for use in atmospheric models, Atmos. Chem. Phys., 11, 4039-4072, doi:10.5194/acp-11-4039-2011, 2011.

Akagi, S. K., Craven, J. S., Taylor, J. W., McMeeking, G. R., Yokelson, R. J., Burling, I. R., Urbanski, S. P., Wold, C. E., Seinfeld, J. H., Coe, H., Alvarado, M. J., and Weise, D. R.: Evolution of trace gases and particles emitted by a chaparral fire in California, Atmos. Chem. Phys., 12, 1397-1421, doi:10.5194/acp-12-13972012, 2012.

Alfarra, M. R., Coe, H., Allan, J. D., Bower, K. N., Boudries, H., Canagaratna, M. R., Jimenez, J. L., Jayne, J. T., Garforth, A. A., Li, S. M., and Worsnop, D. R.: Characterization of urban and rural organic particulate in the Lower Fraser Valley using two Aerodyne Aerosol Mass Spectrometers, Atmos. Environ.,38, 5745-5758, doi:10.1016/j.atmosenv.2004.01.054, 2004.

Alfarra, M. R., Prévôt, A. S. H., Szidat, S., Sandradewi, J., Weimer, S., Lanz, V. A., Schreiber, D., Mohr, M., and Baltensperger, U. Identification of the mass spectral signature of organic aerosols from wood burning emissions, Environ. Sci. Tech., 41, 57705777, doi:10.1021/es062289b, 2007. 
Andreae, M. O., Atlas, E. Cachier, H., Cofer III, W. R., Harris, G. W., Helas, G., Koppmann, R., Lacaux, J.-P., and Ward, D. E.: Trace gas and aerosol emissions from savanna fires, in: Biomass Burning and Global Change, edited by: Levine, S., 278-295, MIT Press, Cambridge, Mass., 1996.

Andreae, M. O. and Merlet, P.: Emission of trace gases and aerosols from biomass burning, Global Biogeochem. Cy., 15, 955-966, 2001.

Bahreini, R., Jimenez, J. L., Wang, J., Flagan, R. C., Seinfeld, J. H., Jayne, J. T., and Worsnop, D. R.: Aircraft-based aerosol size and composition measurements during ACE-Asia using an Aerodyne aerosol mass spectrometer, J. Geophys. Res.-Atmos., 108, 8645, doi:10.1029/2002jd003226, 2003.

Bond, T. C., Streets, D. G., Yarber, K. F., Nelson, S. M., Woo, J. H., and Klimont, Z.: A technology-based global inventory of black and organic carbon emissions from combustion, J. Geophys. Res.-Atmos., 109, D14203, doi:10.1029/2003jd003697, 2004.

Burling, I. R., Yokelson, R. J., Akagi, S. K., Urbanski, S. P., Wold, C. E., Griffith, D. W. T., Johnson, T. J., Reardon, J., and Weise, D. R.: Airborne and ground-based measurements of the trace gases and particles emitted by prescribed fires in the United States, Atmos. Chem. Phys., 11, 12197-12216, doi:10.5194/acp11-12197-2011, 2011.

Canagaratna, M. R., Jayne, J. T., Jimenez, J. L., Allan, J. D., Alfarra, M. R., Zhang, Q., Onasch, T. B., Drewnick, F., Coe, H., Middlebrook, A., Delia, A., Williams, L. R., Trimborn, A. M., Northway, M. J., DeCarlo, P. F., Kolb, C. E., Davidovits, P., and Worsnop, D. R.: Chemical and microphysical characterization of ambient aerosols with the aerodyne aerosol mass spectrometer, Mass Spectrom. Rev., 26, 185-222, doi:10.1002/mas.20115, 2007.

Capes, G., B. Johnson, G. McFiggans, P. I. Williams, J. Haywood, and H. Coe: Aging of biomass burning aerosols over West Africa: Aircraft measurements of chemical composition, microphysical properties, and emission ratios, J. Geophys. Res.-Atmos., 113, D00C15, doi:10.1029/2008jd009845, 2008.

Crosier, J., Allan, J. D., Coe, H., Bower, K. N., Formenti, P., and Williams, P. I.: Chemical composition of summertime aerosol in the Po Valley (Italy), northern Adriatic and Black Sea, Q. J. Roy. Meteor. Soc., 133, 61-75, doi:10.1002/qj.88, 2007.

Crounse, J. D., DeCarlo, P. F., Blake, D. R., Emmons, L. K., Campos, T. L., Apel, E. C., Clarke, A. D., Weinheimer, A. J., McCabe, D. C., Yokelson, R. J., Jimenez, J. L., and Wennberg, P. O.: Biomass burning and urban air pollution over the Central Mexican Plateau, Atmos. Chem. Phys., 9, 4929-4944, doi:10.5194/acp-9-4929-2009, 2009.

Crutzen, P. J. and Andreae, M. O.: Biomass Burning in the Tropics Impact on Atmospheric Chemistry and Biogeochemical Cycles, Science, 250, 1669-1678, doi:10.1126/science.250.4988.1669, 1990.

Cubison, M. J., Ortega, A. M., Hayes, P. L., Farmer, D. K., Day, D., Lechner, M. J., Brune, W. H., Apel, E., Diskin, G. S., Fisher, J. A., Fuelberg, H. E., Hecobian, A., Knapp, D. J., Mikoviny, T., Riemer, D., Sachse, G. W., Sessions, W., Weber, R. J., Weinheimer, A. J., Wisthaler, A., and Jimenez, J. L.: Effects of aging on organic aerosol from open biomass burning smoke in aircraft and laboratory studies, Atmos. Chem. Phys., 11, 12049-12064, doi:10.5194/acp-11-12049-2011, 2011.
Damoah, R., Spichtinger, N., Servranckx, R., Fromm, M., Eloranta, E. W., Razenkov, I. A., James, P., Shulski, M., Forster, C., and Stohl, A.: A case study of pyro-convection using transport model and remote sensing data, Atmos. Chem. Phys., 6, 173185, doi:10.5194/acp-6-173-2006, 2006.

DeCarlo, P. F., Dunlea, E. J., Kimmel, J. R., Aiken, A. C., Sueper, D., Crounse, J., Wennberg, P. O., Emmons, L., Shinozuka, Y., Clarke, A., Zhou, J., Tomlinson, J., Collins, D. R., Knapp, D., Weinheimer, A. J., Montzka, D. D., Campos, T., and Jimenez, J. L.: Fast airborne aerosol size and chemistry measurements above Mexico City and Central Mexico during the MILAGRO campaign, Atmos. Chem. Phys., 8, 4027-4048, doi:10.5194/acp-84027-2008, 2008.

DeCarlo, P. F., Ulbrich, I. M., Crounse, J., de Foy, B., Dunlea, E. J., Aiken, A. C., Knapp, D., Weinheimer, A. J., Campos, T., Wennberg, P. O., and Jimenez, J. L.: Investigation of the sources and processing of organic aerosol over the Central Mexican Plateau from aircraft measurements during MILAGRO, Atmos. Chem. Phys., 10, 5257-5280, doi:10.5194/acp-10-52572010, 2010.

Di Carlo, P., Aruffo, E., Busilacchio, M., Giammaria, F., DariSalisburgo, C., Biancofiore, F., Visconti, G., Lee, J., Moller, S., Reeves, C. E., Bauguitte, S., Forster, G., Jones, R. L., and Ouyang, B.: Aircraft based four-channel thermal dissociation laser induced fluorescence instrument for simultaneous measurements of $\mathrm{NO}_{2}$, total peroxy nitrate, total alkyl nitrate, and $\mathrm{HNO}_{3}$, Atmos. Meas. Tech., 6, 971-980, doi:10.5194/amt-6-971-2013, 2013.

Drewnick, F., Hings, S. S., DeCarlo, P. F., Jayne, J. T., Gonin, M., Fuhrer, K., Weimer, S., Jimenez, J. L., Demerjian, K. L., Borrmann, S., and Worsnop, D. R.: A new time-of-flight aerosol mass spectrometer (TOF-AMS) - Instrument description and first field deployment, Aerosol Sci. Tech., 39, 637-658, doi:10.1080/02786820500182040, 2005.

Ferek, R. J., Reid, J. S., Hobbs, P. V., Blake, D. R., and Liousse, C.: Emission factors of hydrocarbons, halocarbons, trace gases and particles from biomass burning in Brazil, J. Geophys. Res.Atmos., 103, 32107-32118, 1998.

Forster, P., Artaxo, P., Berntse, T., Betts, R., Fahey, D. W., Haywood, J., Lean, J., Lowe, D. C., Myhre, G., Nganga, J., Prinn, R., Raga, G., Schulz, M., Van Dorland, R., Bodeker, G., Boucher, O., Collins, W. D., Conway, T. J., Dlugokencky, E., Elkins, J. W., Etheridge, D., Foukal, P., Fraser, P., Geller, M., Joos, F., Keeling, C. D., Keeling, R., Kinne, S., Lassey, K., Lohmann, U., Manning, A. C., Montzka, S., Oram, D., O’Shaughnessy, K., Piper, S., Plattner, G.-K., Ponater, M., Ramankutty, N., Reid, G., Rind, D., Rosenlof, K., Sausen, R., Schwarzkopf, D., Solanki, S. K., Stenchikov, G., Stuber, N., Takemura, T., Textor, C., Wang, R., Weiss, R., and Whorf, T.: Changes in atmospheric constituents and in radiative forcing, in: Climate Change 2007: The Physical Science Basis, Contribution of Working Group I to the Fourth Assessment Report of the Intergovernmental Panel on Climate Change, edited by: Solomon, S. D., Qin, M., Manning, Z., Chen, M., Marquis, K. B., Averyt, M. T., and Miller, H. L., Cambridge University Press, Cambridge, UK and New York, NY, USA, 129-234, 2007.

Fromm, M., R. Bevilacqua, R. Servranckx, J. Rosen, J. P. Thayer, J. Herman, and D. Larko: Pyro-cumulonimbus injection of smoke to the stratosphere: Observations and impact of a super blowup 
in northwestern Canada on 3-4 August 1998, J. Geophys. Res.Atmos., 110, D08205, doi:10.1029/2004jd005350, 2005.

Gao, S., Hegg, D. A., Hobbs, P. V., Kirchstetter, T. W., Magi, B. I., and Sadilek, M.: Water-soluble organic components in aerosols associated with savanna fires in southern Africa: Identification, evolution, and distribution, J. Geophys. Res.-Atmos., 108, 8491, doi:10.1029/2002jd002324, 2003.

Grieshop, A. P., Logue, J. M., Donahue, N. M., and Robinson, A. L.: Laboratory investigation of photochemical oxidation of organic aerosol from wood fires 1: measurement and simulation of organic aerosol evolution, Atmos. Chem. Phys., 9, 1263-1277, doi:10.5194/acp-9-1263-2009, 2009.

Griffin, D., Walker, K. A., Franklin, J. E., Parrington, M., Whaley, C., Hopper, J., Drummond, J. R., Palmer, P. I., Strong, K., Duck, T. J., Abboud, I., Bernath, P. F., Clerbaux, C., Coheur, P.F., Curry, K. R., Dan, L., Hyer, E., Kliever, J., Lesins, G., Maurice, M., Saha, A., Tereszchuk, K., and Weaver, D.: Investigation of $\mathrm{CO}, \mathrm{C}_{2} \mathrm{H}_{6}$ and aerosols in a boreal fire plume over eastern Canada during BORTAS 2011 using ground- and satellite-based observations and model simulations, Atmos. Chem. Phys., 13, 10227-10241, doi:10.5194/acp-13-10227-2013, 2013.

Hallquist, M., Wenger, J. C., Baltensperger, U., Rudich, Y., Simpson, D., Claeys, M., Dommen, J., Donahue, N. M., George, C., Goldstein, A. H., Hamilton, J. F., Herrmann, H., Hoffmann, T., Iinuma, Y., Jang, M., Jenkin, M. E., Jimenez, J. L., Kiendler-Scharr, A., Maenhaut, W., McFiggans, G., Mentel, Th. F., Monod, A., Prévôt, A. S. H., Seinfeld, J. H., Surratt, J. D., Szmigielski, R., and Wildt, J.: The formation, properties and impact of secondary organic aerosol: current and emerging issues, Atmos. Chem. Phys., 9, 5155-5236, doi:10.5194/acp-9-51552009, 2009.

Hecobian, A., Liu, Z., Hennigan, C. J., Huey, L. G., Jimenez, J. L., Cubison, M. J., Vay, S., Diskin, G. S., Sachse, G. W., Wisthaler, A., Mikoviny, T., Weinheimer, A. J., Liao, J., Knapp, D. J., Wennberg, P. O., Kürten, A., Crounse, J. D., Clair, J. St., Wang, Y., and Weber, R. J.: Comparison of chemical characteristics of 495 biomass burning plumes intercepted by the NASA DC-8 aircraft during the ARCTAS/CARB-2008 field campaign, Atmos. Chem. Phys., 11, 13325-13337, doi:10.5194/acp-1113325-2011, 2011.

Hennigan, C. J., Miracolo, M. A., Engelhart, G. J., May, A. A., Presto, A. A., Lee, T., Sullivan, A. P., McMeeking, G. R., Coe, H., Wold, C. E., Hao, W.-M., Gilman, J. B., Kuster, W. C., de Gouw, J., Schichtel, B. A., Collett Jr., J. L., Kreidenweis, S. M., and Robinson, A. L.: Chemical and physical transformations of organic aerosol from the photo-oxidation of open biomass burning emissions in an environmental chamber, Atmos. Chem. Phys., 11, 7669-7686, doi:10.5194/acp-11-7669-2011, 2011.

Heringa, M. F., DeCarlo, P. F., Chirico, R., Tritscher, T., Dommen, J., Weingartner, E., Richter, R., Wehrle, G., Prévôt, A. S. H., and Baltensperger, U.: Investigations of primary and secondary particulate matter of different wood combustion appliances with a high-resolution time-of-flight aerosol mass spectrometer, Atmos. Chem. Phys., 11, 5945-5957, doi:10.5194/acp-11-59452011, 2011.

Higuchi, K., Worthy, D., Chan, D., and Shashkov, A.: Regional source/sink impact on the diurnal, seasonal and inter-annual variations in atmospheric $\mathrm{CO}_{2}$ at a boreal forest site in Canada,
Tellus B, 55, 115-125, doi:10.1034/j.1600-0889.2003.00062.x, 2003.

Iinuma, Y., Bruggemann, E., Gnauk, T., Muller, K., Andreae, M. O., Helas, G., Parmar, R., and Herrmann, H.: Source characterization of biomass burning particles: The combustion of selected European conifers, African hardwood, savanna grass, and German and Indonesian peat, J. Geophys. Res.-Atmos., 112, D08209, doi:10.1029/2006jd007120, 2007.

Jimenez, J. L., Canagaratna, M. R., Donahue, N. M., Prévôt, A. S. H., Zhang, Q., Kroll, J. H., DeCarlo, P. F., Allan, J. D., Coe, H., Ng, N. L., Aiken, A. C., Docherty, K. S., Ulbrich, I. M., Grieshop, A. P., Robinson, A. L., Duplissy, J., Smith, J. D., Wilson, K. R., Lanz, V. A., Hueglin, C., Sun, Y. L., Tian, J., Laaksonen, A., Raatikainen, T., Rautiainen, J., Vaattovaara, P., Ehn, M., Kulmala, M., Tomlinson, J. M., Collins, D. R., Cubison, M. J., Dunlea, E. J., Huffman, J. A., Onasch, T. B., Alfarra, M. R., Williams, P. I., Bower, K., Kondo, Y., Schneider, J., Drewnick, F., Borrmann, S., Weimer, S., Demerjian, K., Salcedo, D., Cottrell, L., Griffin, R., Takami, A., Miyoshi, T., Hatakeyama, S., Shimono, A., Sun, J. Y., Zhang, Y. M., Dzepina, K., Kimmel, J. R., Sueper, D., Jayne, J. T., Herndon, S. C., Trimborn, A. M., Williams, L. R., Wood, E. C., Middlebrook, A. M., Kolb, C. E., Baltensperger, U., Worsnop, D. R.: Evolution of Organic Aerosols in the Atmosphere, Science, 326, 1525-1529, doi:10.1126/science.1180353, 2009.

Jolleys, M. D., Coe, H., McFiggans, G., Capes, G., Allan, J. D., Crosier, J., Williams, P. I., Allen, G., Bower, K. N., Jimenez, J. L., Russell, L. M., Grutter, M., and Baumgardner, D.: Characterizing the Aging of Biomass Burning Organic Aerosol by Use of Mixing Ratios: A Meta-analysis of Four Regions, Environ. Sci. Tech., 46, 13093-13102, doi:10.1021/es302386v, 2012.

Jolleys, M. D., Coe, H., McFiggans, G., McMeeking, G. R., Lee, T., Kreidenweis, S. M., Collett, J. L., and Sullivan, A. P.: Organic aerosol emission ratios from the laboratory combustion of biomass fuels, J. Geophys. Res. Atmos., 119, 22, 12850-12871, doi:10.1002/2014JD021589, 2014.

Kleinman, L. I., Springston, S. R., Daum, P. H., Lee, Y.-N., Nunnermacker, L. J., Senum, G. I., Wang, J., Weinstein-Lloyd, J., Alexander, M. L., Hubbe, J., Ortega, J., Canagaratna, M. R., and Jayne, J.: The time evolution of aerosol composition over the Mexico City plateau, Atmos. Chem. Phys., 8, 1559-1575, doi:10.5194/acp-8-1559-2008, 2008.

Kondo, Y., Matsui, H., Moteki, N., Sahu, L., Takegawa, N., Kajino, M., Zhao, Y., Cubison, M. J., Jimenez, J. L., Vay, S., Diskin, G. S., Anderson, B. , Wisthaler, A., Mikoviny, T., Fuelberg, H. E., Blake, D. R., Huey, G. , Weinheimer, A. J., Knapp, D. J., Brune, W. H.: Emissions of black carbon, organic, and inorganic aerosols from biomass burning in North America and Asia in 2008, J. Geophys. Res.-Atmos., 116, D08204, doi:10.1029/2010jd015152, 2011.

Le Breton, M., McGillen, M. R., Muller, J. B. A., Bacak, A., Shallcross, D. E., Xiao, P., Huey, L. G., Tanner, D., Coe, H., and Percival, C. J.: Airborne observations of formic acid using a chemical ionization mass spectrometer, Atmos. Meas. Tech., 5, 30293039, doi:10.5194/amt-5-3029-2012, 2012.

Le Breton, M., Bacak, A., Muller, J. B. A., O'Shea, S. J., Xiao, P., Ashfold, M. N. R., Cooke, M. C., Batt, R., Shallcross, D. E., Oram, D. E., Forster, G., Bauguitte, S. J.-B., Palmer, P. I., Parrington, M., Lewis, A. C., Lee, J. D., and Percival, C. 
J.: Airborne hydrogen cyanide measurements using a chemical ionisation mass spectrometer for the plume identification of biomass burning forest fires, Atmos. Chem. Phys., 13, 92179232, doi:10.5194/acp-13-9217-2013, 2013.

Lee, T., Sullivan, A. P., Mack, L., Jimenez, J. L., Kreidenweis, S. M. , Onasch, T. B., Worsnop, D. R., Malm, W., Wold, C. E., Hao, W. M., Collett, J. L..: Chemical Smoke Marker Emissions During Flaming and Smoldering Phases of Laboratory Open Burning of Wildland Fuels, Aerosol Sci. Tech., 44, I-V, doi:10.1080/02786826.2010.499884, 2010.

Li, Q. B., Jacob, D. J., Bey, I., Yantosca, R. M., Zhao, Y. J., Kondo, Y., and Notholt, J.: Atmospheric hydrogen cyanide (HCN): Biomass burning source, ocean sink?, Geophys. Res. Lett., 27, 357-360, doi:10.1029/1999g1010935, 2000.

Liousse, C., Devaux, C., Dulac, F., and Cachier, H.: Aging of Savanna Biomass Burning Aerosols - Consequences on their Optical Properties, J. Atmos. Chem., 22, 1-17, doi:10.1007/bf00708178, 1995.

Mason, S. A., Field, R. J., Yokelson, R. J., Kochivar, M. A., Tinsley, M. R., Ward, D. E., and Hao, W. M.: Complex effects arising in smoke plume simulations due to inclusion of direct emissions of oxygenated organic species from biomass combustion, J. Geophys. Res.-Atmos., 106, 12527-12539, 2001.

McMeeking, G. R., Kreidenweis, S. M., Baker, S., Carrico, C. M., Chow, J. C., Collett, Jr., J. L., Hao, W. M. , Holden, A. S., Kirchstetter, T. W., Malm, W. C., Moosmueller, H., Sullivan, A. P., and Wold, C. E.: Emissions of trace gases and aerosols during the open combustion of biomass in the laboratory, J. Geophys. Res.-Atmos., 114, D19210, doi:10.1029/2009jd011836, 2009.

Morgan, W. T., Allan, J. D., Bower, K. N., Capes, G., Crosier, J., Williams, P. I., and Coe, H.: Vertical distribution of sub-micron aerosol chemical composition from North-Western Europe and the North-East Atlantic, Atmos. Chem. Phys., 9, 5389-5401, doi:10.5194/acp-9-5389-2009, 2009.

Morgan, W. T., Allan, J. D., Bower, K. N., Highwood, E. J., Liu, D., McMeeking, G. R., Northway, M. J., Williams, P. I., Krejci, R., and Coe, H.: Airborne measurements of the spatial distribution of aerosol chemical composition across Europe and evolution of the organic fraction, Atmos. Chem. Phys., 10, 4065-4083, doi:10.5194/acp-10-4065-2010, 2010.

Ng, N. L., Canagaratna, M. R., Zhang, Q., Jimenez, J. L., Tian, J., Ulbrich, I. M., Kroll, J. H., Docherty, K. S., Chhabra, P. S., Bahreini, R., Murphy, S. M., Seinfeld, J. H., Hildebrandt, L., Donahue, N. M., DeCarlo, P. F., Lanz, V. A., Prévôt, A. S. H., Dinar, E., Rudich, Y., and Worsnop, D. R.: Organic aerosol components observed in Northern Hemispheric datasets from Aerosol Mass Spectrometry, Atmos. Chem. Phys., 10, 46254641, doi:10.5194/acp-10-4625-2010, 2010.

Nowak, J. B., Neuman, J. A., Kozai, K., Huey, L. G., Tanner, D. J., Holloway, J. S., Ryerson, T. B., Frost, G. J., McKeen, S. A., and Fehsenfeld, F. C.: A chemical ionization mass spectrometry technique for airborne measurements of ammonia, J. Geophys. Res.-Atmos., 112, D10S02, doi:10.1029/2006jd007589, 2007.

O'Shea, S. J., Allen, G., Gallagher, M. W., Bauguitte, S. J.-B., Illingworth, S. M., Le Breton, M., Muller, J. B. A., Percival, C. J., Archibald, A. T., Oram, D. E., Parrington, M., Palmer, P. I., and Lewis, A. C.: Airborne observations of trace gases over boreal Canada during BORTAS: campaign climatology, air mass anal- ysis and enhancement ratios, Atmos. Chem. Phys., 13, 1245112467, doi:10.5194/acp-13-12451-2013, 2013a.

O'Shea, S. J., Bauguitte, S. J.-B., Gallagher, M. W., Lowry, D., and Percival, C. J.: Development of a cavity-enhanced absorption spectrometer for airborne measurements of $\mathrm{CH}_{4}$ and $\mathrm{CO}_{2}$, Atmos. Meas. Tech., 6, 1095-1109, doi:10.5194/amt-6-1095-2013, $2013 b$.

Palmer, P. I., Parrington, M., Lee, J. D., Lewis, A. C., Rickard, A. R., Bernath, P. F., Duck, T. J., Waugh, D. L., Tarasick, D. W., Andrews, S., Aruffo, E., Bailey, L. J., Barrett, E., Bauguitte, S. J.-B., Curry, K. R., Di Carlo, P., Chisholm, L., Dan, L., Forster, G., Franklin, J. E., Gibson, M. D., Griffin, D., Helmig, D., Hopkins, J. R., Hopper, J. T., Jenkin, M. E., Kindred, D., Kliever, J., Le Breton, M., Matthiesen, S., Maurice, M., Moller, S., Moore, D. P., Oram, D. E., O'Shea, S. J., Owen, R. C., Pagniello, C. M. L. S., Pawson, S., Percival, C. J., Pierce, J. R., Punjabi, S., Purvis, R. M., Remedios, J. J., Rotermund, K. M., Sakamoto, K. M., da Silva, A. M., Strawbridge, K. B., Strong, K., Taylor, J., Trigwell, R., Tereszchuk, K. A., Walker, K. A., Weaver, D., Whaley, C., and Young, J. C.: Quantifying the impact of BOReal forest fires on Tropospheric oxidants over the Atlantic using Aircraft and Satellites (BORTAS) experiment: design, execution and science overview, Atmos. Chem. Phys., 13, 6239-6261, doi:10.5194/acp-13-6239-2013, 2013.

Parrington, M., Palmer, P. I., Henze, D. K., Tarasick, D. W., Hyer, E. J., Owen, R. C., Helmig, D., Clerbaux, C., Bowman, K. W., Deeter, M. N., Barratt, E. M., Coheur, P.-F., Hurtmans, D., Jiang, Z., George, M., and Worden, J. R.: The influence of boreal biomass burning emissions on the distribution of tropospheric ozone over North America and the North Atlantic during 2010, Atmos. Chem. Phys., 12, 2077-2098, doi:10.5194/acp-12-20772012, 2012.

Parrington, M., Palmer, P. I., Lewis, A. C., Lee, J. D., Rickard, A. R., Di Carlo, P., Taylor, J. W., Hopkins, J. R., Punjabi, S., Oram, D. E., Forster, G., Aruffo, E., Moller, S. J., Bauguitte, S. J.-B., Allan, J. D., Coe, H., and Leigh, R. J.: Ozone photochemistry in boreal biomass burning plumes, Atmos. Chem. Phys., 13, 73217341, doi:10.5194/acp-13-7321-2013, 2013.

Petzold, A., Weinzierl, B., Huntrieser, H., Stohl, A., Real, E., Cozic, J., Fiebig, M., Hendricks, J., Lauer, A., Law, K., Roiger, A., Schlager, H., and Weingartner, E.: Perturbation of the European free troposphere aerosol by North American forest fire plumes during the ICARTT-ITOP experiment in summer 2004, Atmos. Chem. Phys., 7, 5105-5127, doi:10.5194/acp-7-51052007, 2007.

Reid, J. S. and Hobbs, P. V.: Physical and optical properties of young smoke from individual biomass fires in Brazil, J. Geophys. Res.Atmos., 103, 32013-32030, 1998.

Reid, J. S., Koppmann, R., Eck, T. F., and Eleuterio, D. P.: A review of biomass burning emissions part II: intensive physical properties of biomass burning particles, Atmos. Chem. Phys., 5, 799825, doi:10.5194/acp-5-799-2005, 2005.

Schneider, J., Weimer, S., Drewnick, F., Borrmann, S., Helas, G., Gwaze, P., Schmid, O., Andreae, M. O., and Kirchner, U.: Mass spectrometric analysis and aerodynamic properties of various types of combustion-related aerosol particles, Int. J. Mass Spectrom., 258, 37-49, doi:10.1016/j.ijms.2006.07.008, 2006. 
Schwarz, J. P., Gao, R. S., Fahey, D. W., Thomson, D. S., Watts, L. A., Wilson, J. C., Reeves, J. M., Darbeheshti, M., Baumgardner, D. G., Kok, G. L., Chung, S. H., Schulz, M., Hendricks, J., Lauer, A., Kaercher, B., Slowik, J. G., Rosenlof, K. H., Thompson, T. L., Langford, A. O., Loewenstein, M., and Aikin, K. C.: Single-particle measurements of midlatitude black carbon and light-scattering aerosols from the boundary layer to the lower stratosphere, J. Geophys. Res.-Atmos., 111, D16207, doi:10.1029/2006jd007076, 2006.

Simoneit, B. R. T., Schauer, J. J., Nolte, C. G., Oros, D. R., Elias, V. O., Fraser, M. P., Rogge, W. F., and Cass, G. R.: Levoglucosan, a tracer for cellulose in biomass burning and atmospheric particles, Atmos. Environ., 33, 173-182, doi:10.1016/s13522310(98)00145-9, 1999.

Sinha, P., Hobbs, P. V., Yokelson, R. J., Bertschi, I. T., Blake, D. R., Simpson, I. J., Gao, S., Kirchstetter, T. W., and Novakov, T.: Emissions of trace gases and particles from savanna fires in southern Africa, J. Geophys. Res.-Atmos., 108, 32, doi:10.1029/2002jd002325, 2003.

Slowik, J. G., Stroud, C., Bottenheim, J. W., Brickell, P. C., Chang, R. Y.-W., Liggio, J., Makar, P. A., Martin, R. V., Moran, M. D., Shantz, N. C., Sjostedt, S. J., van Donkelaar, A., Vlasenko, A., Wiebe, H. A., Xia, A. G., Zhang, J., Leaitch, W. R., and Abbatt, J. P. D.: Characterization of a large biogenic secondary organic aerosol event from eastern Canadian forests, Atmos. Chem. Phys., 10, 2825-2845, doi:10.5194/acp-10-2825-2010, 2010.

Sullivan, A. P., Holden, A. S., Patterson, L. A., McMeeking, G. R., Kreidenweis, S. M., Malm, W. C., Hao, W. M., Wold, C. E., and Collett, Jr., J. L.: A method for smoke marker measurements and its potential application for determining the contribution of biomass burning from wildfires and prescribed fires to ambient $\mathrm{PM}_{2.5}$ organic carbon, J. Geophys. Res.-Atmos., 113, D22302, doi:10.1029/2008jd010216, 2008.

Taylor, J. W., Allan, J. D., Allen, G., Coe, H., Williams, P. I., Flynn, M. J., Le Breton, M., Muller, J. B. A., Percival, C. J., Oram, D., Forster, G., Lee, J. D., Rickard, A. R., Parrington, M., and Palmer, P. I.: Size-dependent wet removal of black carbon in Canadian biomass burning plumes, Atmos. Chem. Phys., 14, 13755-13771, doi:10.5194/acp-14-13755-2014, 2014.

Textor, C., Schulz, M., Guibert, S., Kinne, S., Balkanski, Y., Bauer, S., Berntsen, T., Berglen, T., Boucher, O., Chin, M., Dentener, F., Diehl, T., Easter, R., Feichter, H., Fillmore, D., Ghan, S., Ginoux, P., Gong, S., Grini, A., Hendricks, J., Horowitz, L., Huang, P., Isaksen, I., Iversen, I., Kloster, S., Koch, D., Kirkevåg, A., Kristjansson, J. E., Krol, M., Lauer, A., Lamarque, J. F., Liu, X., Montanaro, V., Myhre, G., Penner, J., Pitari, G., Reddy, S., Seland, $\varnothing .$, Stier, P., Takemura, T., and Tie, X.: Analysis and quantification of the diversities of aerosol life cycles within AeroCom, Atmos. Chem. Phys., 6, 1777-1813, doi:10.5194/acp-6-1777-2006, 2006.

Vay, S. A., Choi, Y., Vadrevu, K. P., Blake, D. R., Tyler, S. C., Wisthaler, A., Hecobian, A., Kondo, Y., Diskin, G. S., Sachse, G. W., Woo, J. H., Weinheimer, A. J., Burkhart, J. F., Stohl, A., Wennberg, P. O.: Patterns of $\mathrm{CO}_{2}$ and radiocarbon across high northern latitudes during International Polar Year 2008, J. Geophys. Res.-Atmos., 116, D14301, doi:10.1029/2011jd015643, 2011.
Warneke, C., de Gouw, J. A., Stohl, A., Cooper, O. R., Goldan, P. D., Kuster, W. C., Holloway, J. S., Williams, E. J., Lerner, B. M., McKeen, S. A., Trainer, M., Fehsenfeld, F. C., Atlas, E. L., Donnelly, S. G., Stroud, V., Lueb, A., and Kato, S.: Biomass burning and anthropogenic sources of $\mathrm{CO}$ over New England in the summer 2004, J. Geophys. Res.-Atmos., 111, D23S15, doi:10.1029/2005jd006878, 2006.

Weimer, S., Alfarra, M. R., Schreiber, D., Mohr, M., Prévôt, A. S. $\mathrm{H}$., and Baltensperger, U.: Organic aerosol mass spectral signatures from wood-burning emissions: Influence of burning conditions and wood type, J. Geophys. Res.-Atmos., 113, D10304, doi:10.1029/2007jd009309, 2008.

Yokelson, R. J., Susott, R., Ward, D. E., Reardon, J., and Griffith, D. W. T.: Emissions from smoldering combustion of biomass measured by open-path Fourier transform infrared spectroscopy, J. Geophys. Res.-Atmos., 102, 18865-18877, doi:10.1029/97jd00852, 1997.

Yokelson, R. J., Urbanski, S. P., Atlas, E. L., Toohey, D. W., Alvarado, E. C., Crounse, J. D., Wennberg, P. O., Fisher, M. E., Wold, C. E., Campos, T. L., Adachi, K., Buseck, P. R., and Hao, W. M.: Emissions from forest fires near Mexico City, Atmos. Chem. Phys., 7, 5569-5584, doi:10.5194/acp-7-5569-2007, 2007.

Yokelson, R. J., Crounse, J. D., DeCarlo, P. F., Karl, T., Urbanski, S., Atlas, E., Campos, T., Shinozuka, Y., Kapustin, V., Clarke, A. D., Weinheimer, A., Knapp, D. J., Montzka, D. D., Holloway, J., Weibring, P., Flocke, F., Zheng, W., Toohey, D., Wennberg, P. O., Wiedinmyer, C., Mauldin, L., Fried, A., Richter, D., Walega, J., Jimenez, J. L., Adachi, K., Buseck, P. R., Hall, S. R., and Shetter, R.: Emissions from biomass burning in the Yucatan, Atmos. Chem. Phys., 9, 5785-5812, doi:10.5194/acp-9-5785-2009, 2009.

Zhang, Q., Worsnop, D. R., Canagaratna, M. R., and Jimenez, J. L.: Hydrocarbon-like and oxygenated organic aerosols in Pittsburgh: insights into sources and processes of organic aerosols, Atmos. Chem. Phys., 5, 3289-3311, doi:10.5194/acp-5-32892005, 2005.

Zhang, Q., Jimenez, J. L., Canagaratna, M. R., Allan, J. D., Coe, H., Ulbrich, I., Alfarra, M. R., Takami, A., Middlebrook, A. M., Sun, Y. L., Dzepina, K., Dunlea, E., Docherty, K., DeCarlo, P. F., Salcedo, D., Onasch, T., Jayne, J. T., Miyoshi, T., Shimono, A., Hatakeyama, S., Takegawa, N., Kondo, Y., Schneider, J., Drewnick, F., Borrmann, S., Weimer, S., Demerjian, K., Williams, P., Bower, K., Bahreini, R., Cottrell, L., Griffin, R. J., Rautiainen, J., Sun, J. Y., Zhang, Y. M., and Worsnop, D. R.: Ubiquity and dominance of oxygenated species in organic aerosols in anthropogenically-influenced Northern Hemisphere midlatitudes, Geophys. Res. Lett., 34, L13801, doi:10.1029/2007g1029979, 2007. 